\title{
CONSUMER PURCHASE INTENTIONS REGARDING FAIR- TRADE COFFEE AND THE ROLE OF VIRTUAL REALITY: AN EXPLORATORY STUDY
}

\author{
By \\ Zachary Robichaud \\ Honours BComm, Ryerson University, Toronto, 2017 \\ A thesis \\ presented to Ryerson University \\ in partial fulfillment of the \\ requirements for the degree of \\ Master of Science in Management \\ in the program of Master of Science in Management
}

Toronto, Ontario, Canada, 2019

CZachary Robichaud, 2019 


\section{AUTHOR'S DECLARATION FOR ELECTRONIC SUBMISSION OF A THESIS}

I hereby declare that I am the sole author of this thesis. This is a true copy of the thesis, including any required final revisions, as accepted by my examiners.

I authorize Ryerson University to lend this thesis to other institutions or individuals for the purpose of scholarly research.

I further authorize Ryerson University to reproduce this thesis by photocopying or by other means, in total or in part, at the request of other institutions or individuals for the purpose of scholarly research.

I understand that my thesis may be made electronically available to the public. 
CONSUMER PURCHASE INTENTIONS REGARDING FAIR-TRADE COFFEE AND THE ROLE OF VIRTUAL REALITY: AN

EXPLORATORY STUDY

\author{
Zachary Robichaud \\ Master of Science in Management \\ Specialization of Retail \& Technology \\ Ryerson University 2019
}

\begin{abstract}
$\underline{\text { Abstract }}$
Fair-trade is an alternative approach to trading that has a goal of sustainable development and creating a better opportunity for producers in third world countries. Fair-trade coffee represents the largest category under this umbrella. Globally, Generation Z's consumption and adoption of ethical/sustainable products creates new challenges and opportunities for producers and marketers. Virtual reality has seen to educate, market, and create value with its media richness, presence, interactive, and immersive qualities. As a result, VR has positioned itself to be a very strong communication tool for social scientists and marketers to add value, communicate effective messages, and impact consumer behaviour. This research examines consumer purchase intentions regarding Fair-trade coffee through the lenses of the Theory of Reasoned Action and the exploratory effect of virtual reality in the context of Generation Z.

A first analysis will allow me to outline, present, and test a model regarding Fair-trade coffee consumption in the scope of the Theory of Reasoned Action. Additionally, a second analysis will leverage VR in an exploratory manner to see if this has an effect on the dimensions outlined in the model. The dimensions presented to impact Fair-trade coffee purchase intentions
\end{abstract}


are personal values, knowledge of Fair-trade, general attitudes towards purchasing Fair-trade coffee, and subjective norms.

By analyzing data from 314 respondents, this study found that competence, knowledge of Fair-trade, skepticism, and concern are significant predictors of product interest and likeability. Knowledge of Fair-trade and Skepticism are significant predictors of price acceptability.

Furthermore, subjective norms are a significant predictor of purchase intentions. Lastly, virtual reality was found to have an inconclusive effect on the dimensions outlined in the conceptual model. 


\section{Acknowledgements}

I would like to take this opportunity to thank Dr. Hong Yu for her constant guidance, encouragement, and patience throughout the biggest chapter of my academic career. Without your support, this thesis would not have been possible. To my examination committee, Dr. Martin Pyle, Dr. Mark Lee, and Dr. Hossein Zolfagharinia, thank you for your invaluable feedback as well as your support prior to the defense.

Words cannot describe my gratitude for my family and friends. I would not be standing here today with a completed thesis without your love and encouragement throughout this process. To my parents who constantly push me to my fullest potential and my partner, Kevin, who put up with my late nights and long weekends of work. I am forever thankfull! Thank you to the Ted Rogers School of Management for providing me with this opportunity to work with amazing professors and the ressources necessary to complete this project. 
AUTHOR'S DECLARATION FOR ELECTRONIC SUBMISSION OF A THESIS............................ii

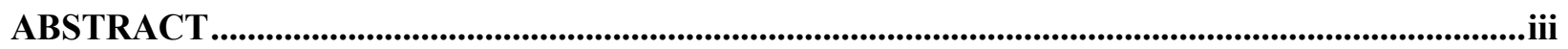

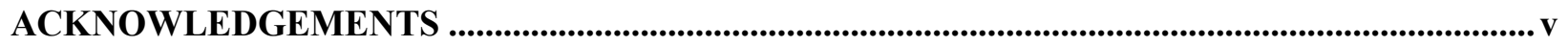

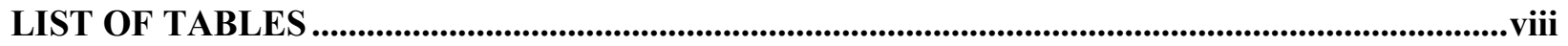

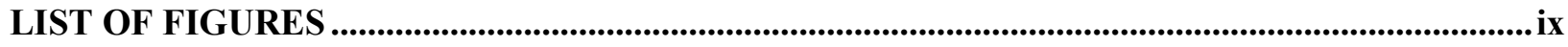

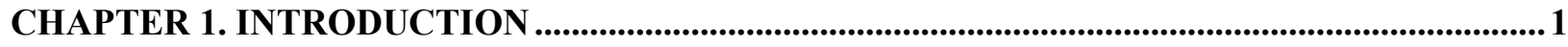

CHAPTER 2. RESEARCH QUESTION, GOALS, AND MOTIVATION ............................................ 7

CHAPTER 3. RESEARCH DESIGN, APPROACH, PARADIGMS ..................................................9

CHAPTER 4. LITERATURE REVIEW AND THEORETICAL BACKGROUND.......................... 11

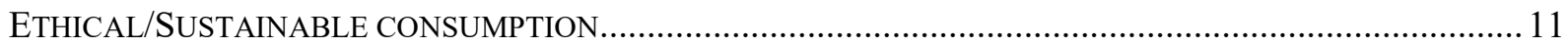

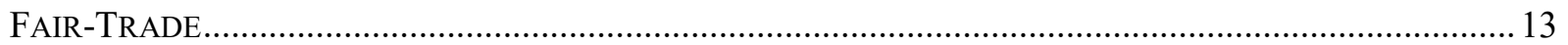

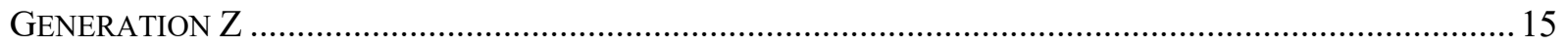

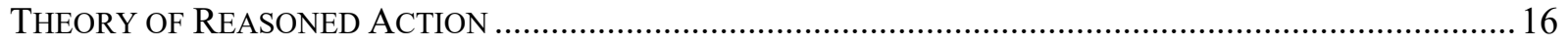

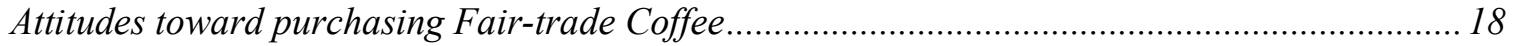

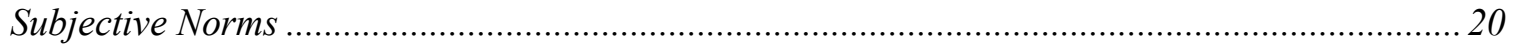

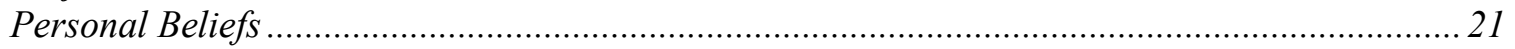

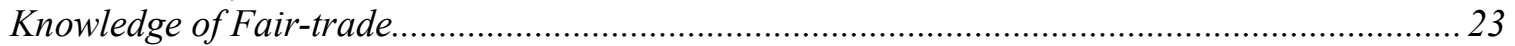

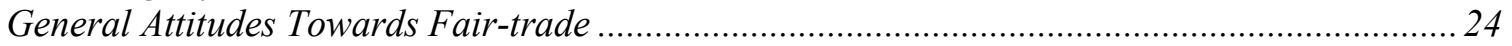

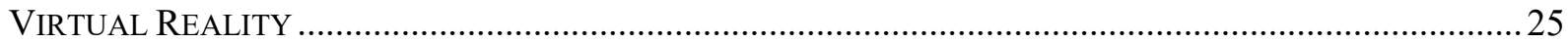

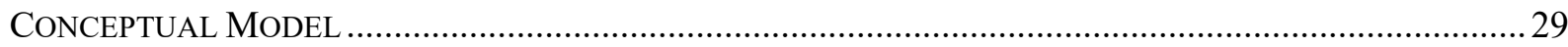

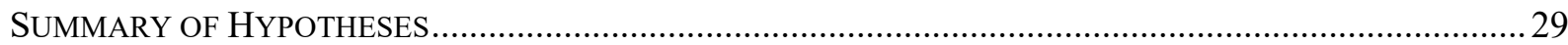

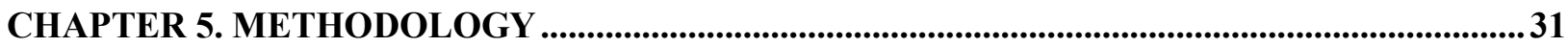

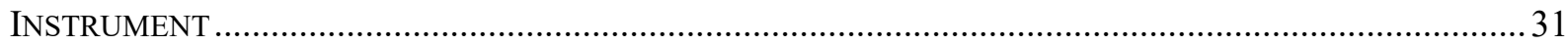

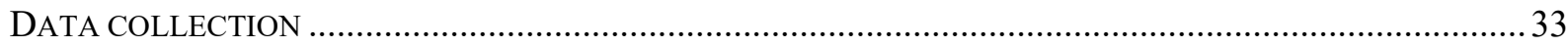

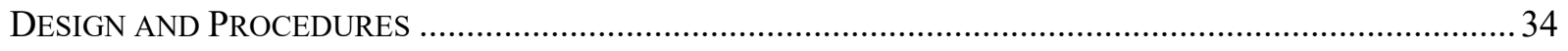

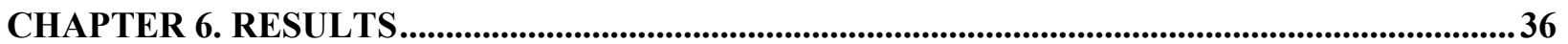

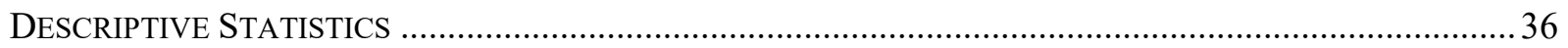

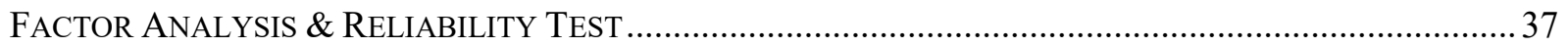

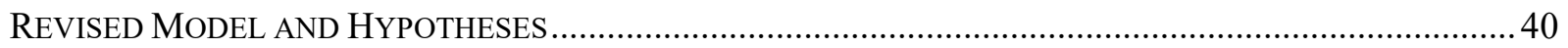

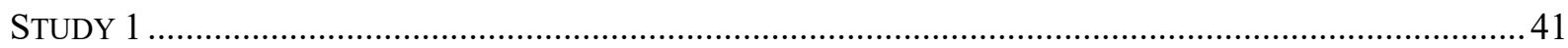

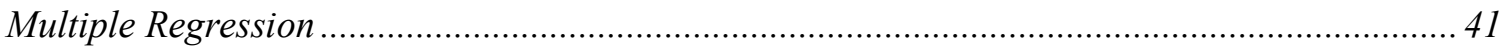

Personal Values, Knowledge about Fair-trade, General attitude towards Fair-trade -> Product

Interest and Likeability)................................................................................................ 41

Personal Values, Knowledge about Fair-trade, General attitude towards Fair-trade-> Price

Acceptability .............................................................................................................. 42

Attitudes towards purchasing Fair-trade coffee, Subjective norms-> Purchase intention............ 42

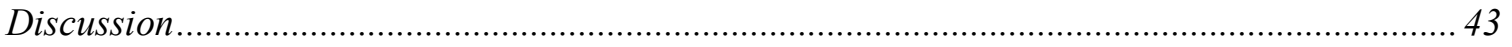

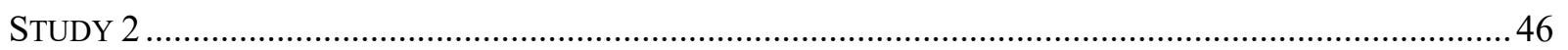

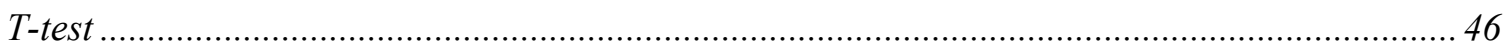

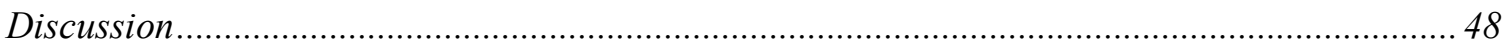

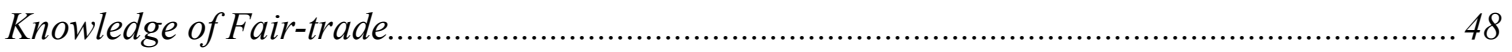

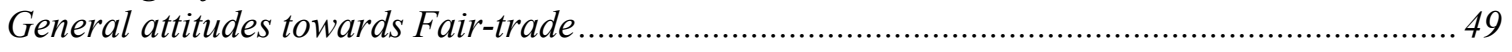

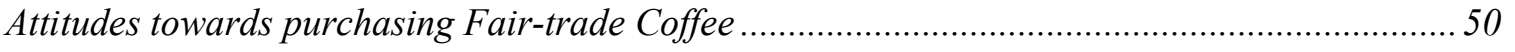

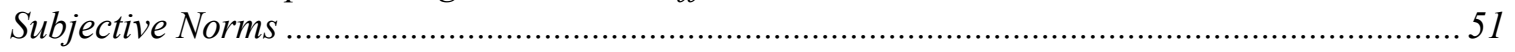




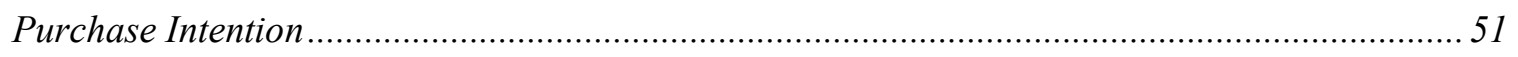

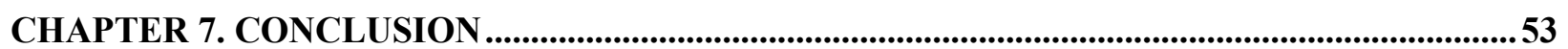

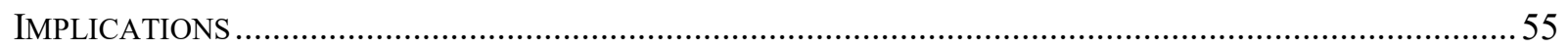

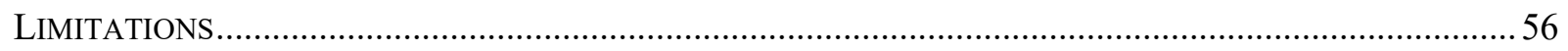

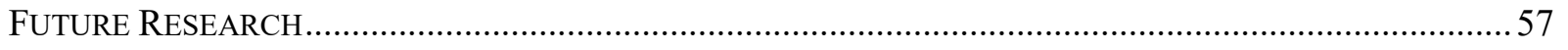

APPENDICES

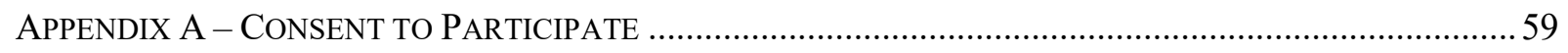

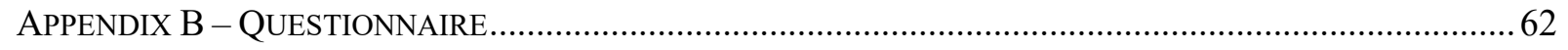

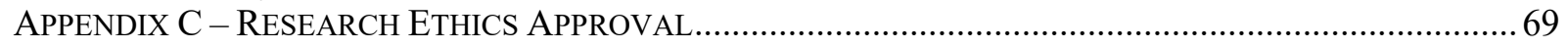

APPENDIX D - VIRTUAL REALITY GOGGLE AND VIDEO .............................................................. 70

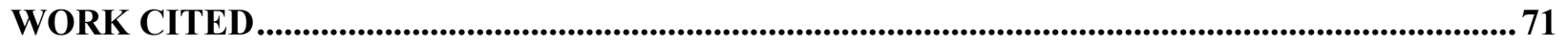


List of Tables

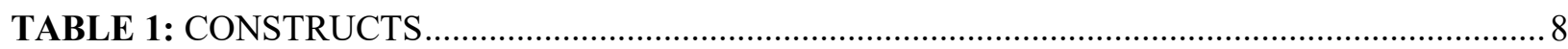

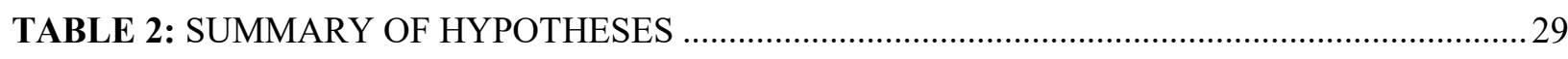

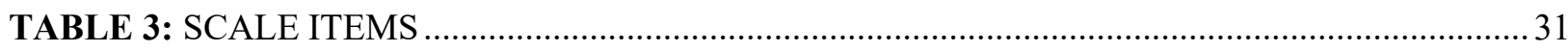

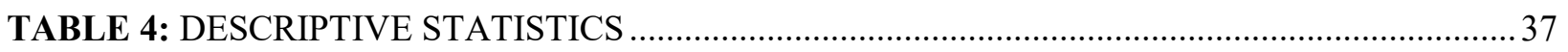

TABLE 5: CORRELATION LOADING AND CRONBACH ALPHA MEASUREMENT OF

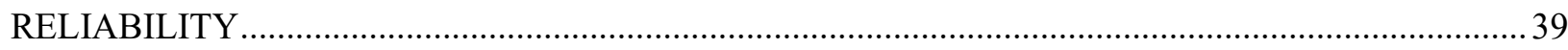

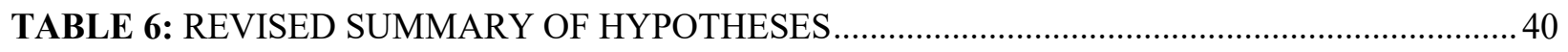

TABLE 7: PRODUCT INTEREST AND LIKEABILITY REGRESSION .......................................... 42

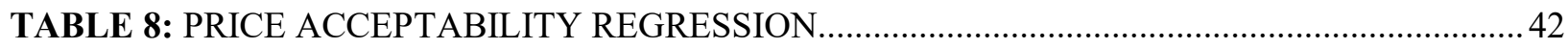

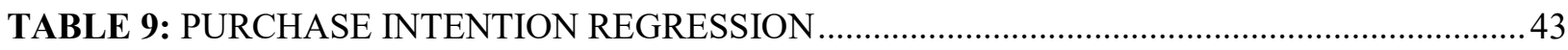

TABLE 10: SUMMARY HYPOTHESES RESULTS STUDY 1 …............................................... 45

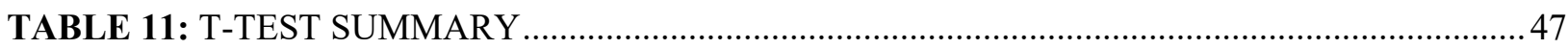




\section{$\underline{\text { List of Figures }}$}

FIGURE 1: THEORY REASONED ACTION (TRA) FRAMEWORK .................................................. 17

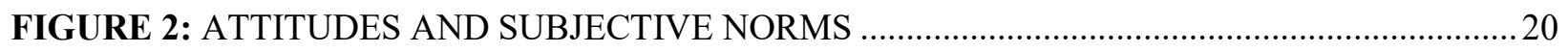

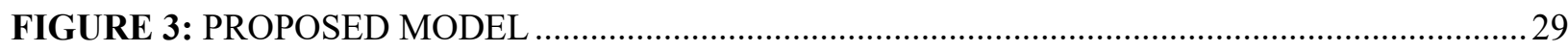

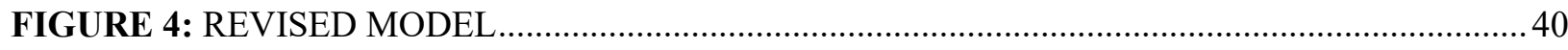

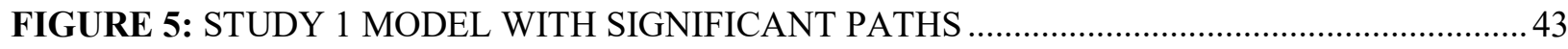

FIGURE 6: BOX PLOT T-TEST RESULTS, KNOWLEDGE OF FAIR-TRADE .............................. 48

FIGURE 7: BOX PLOT T-TEST RESULTS, CONCERN AND SKEPTICISM .................................49

FIGURE 8: BOX PLOT T-TEST RESULTS, PRODUCT INTEREST AND LIKEABILITY AND

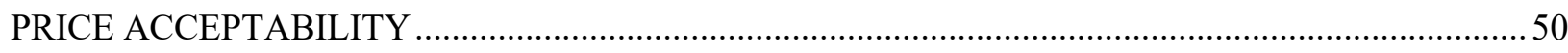

FIGURE 9: BOX PLOT T-TEST RESULTS, SUBJECTIVE NORMS …........................................ 51

FIGURE 10: BOX PLOT T-TEST RESULTS, PURCHASE INTENTION .........................................51 


\section{Chapter 1. Introduction}

Fair-trade (FT) coffee is an alternative approach to trading that has a goal of sustainable development and creating a better opportunity for producers in third world countries. According to the Fairtrade Labelling Organization International, a not-forprofit organization that develops Fair-trade standards across the world, sales of Fair-trade certified products have grown exponentially. Today, there are over 1,599 FT-certified producer organizations worldwide, representing over 1.6 million FT-certified farmers and workers, located in 75 different countries (Fairtrade International, 2018).

The interest of Fair-trade coffee among consumers aged 15-24 (Generation Z) has seen a significant shift from 55\% in 2015 to $72 \%$ in 2016 to being committed to positive social and environmental impact (Nielsen, 2016). A survey of 1000 North Americans showed that more than 50 percent of Generation $\mathrm{Z}$ would be willing to pay more for a sustainable product and ranks ethical business/manufacturing as one of its top factors when purchasing (CGS, 2019). That said, an online survey of more than 30,000 consumers in 60 countries throughout AsiaPacific, Europe, Latin America, the Middle East/Africa and North America found the willingness to pay more for sustainable purchase drivers grew $10-13 \%$ internationally (Nielsen, 2016). As a result, $66 \%$ of these global respondents say they are willing to pay more and purchase products from companies that are committed to positive social and environmental impact, up from 55\% in 2014 and 50\% 2013 (Nielsen, 2016). Altogether, representing a global shift in ethical/sustainable purchase drivers and highlighting Generation $\mathrm{Z}$ as an important market for producers and marketers. 
Fair-trade, in brief, advocates for payment of fair working wages, safe, clean and regulated work spaces, empowerment of artisans, sustainable business practices, fostering of well-being, overarching push for political and social justice, and growing equitable trade (Littrell and Dickson, 1999; Mori, 2000). In turn, Fair-trade would mean buying products from an entity in a developing country that would be more advantageous than traditional free-market principles. Ultimately, creating this notion of "ethical price premium" which allows the producer to market and sell their products at a better price (Bird and Hughes, 1997).

According to Anil Hira and Jared Fernie the three major challenges for Fair-trade products are: (1) defining what Fair-trade really is and how to certify it; (2) increasing Fair-trade awareness and availability; and (3) how much can Fair-trade really do for development (Hira \& Ferrie, 2006). All these challenges affect consumers' overall attitudes and purchasing behaviour towards Fair-trade products. European countries such as the Netherlands, the UK, and Switzerland have created public-private-activist partnerships (Hira \& Ferrie, 2006). Through governmental involvement, by-laws, and public policy, these countries have increased awareness, promoted standards, forced the private sector to respond, and added new formal institutional channels and resources to the Fair-trade movement. In turn, increasing the promotion of these products, enforcement of new regulations, monitoring progress of issues, and overall growth. (Hira $\&$ Ferrie, 2006). As a result, Fair-trade products in these countries are wellrecognized and widely available. Comparatively, Canada has more limited availability of Fairtrade products (like challenge 2) and most Fair-trade coffee is offered in specialty shops, organic food stores, and online retailers (Hira \& Ferrie, 2006). 
The motivation for ethical consumption is often described as purchasing behaviours to fulfill ethical concerns such as human rights, labour conditions and pay gap, animal and human well-being, and environmental/sustainable concerns (Doane, 2001). Research has shown that, in some countries, consumers are willing to pay up to $10 \%$ more in order to purchase Fair-trade coffee products (Pelsmacker et al., 2005). Furthermore, characteristics like younger age, female gender, higher education, and high income may correlate with a higher willingness to pay (Devitiis et al., 2008). The challenges that face the Fair-trade economy are lack of trust in the economic system, the high cost to meet certified standards, Fair-trade practices are not helping the poorest of countries and workers, and the lack of transparency on where the premium is being spent. (Wydick, 2016).

Shen and Eder (2009) define virtual environments as, "A virtual world is a computer based simulated environment created with two- and three-dimensional graphical representations of a physical space. People interact with one another via avatars, which are graphical, 2- or 3-D representations of a user"' (Shen \& Eder, 2009, p. 225). Virtual 3D environments are relatively new marketing channels companies are using to reach their consumers. This tool is used to enhance their brand experience and product engagement (Burke 1997; Shen and Eder 2009). Studies have shown that virtual product experiences to mimic direct product experiences, offers a high degree of interactivity with products and users of the brand (Li et al. 2001; Kim and Forsythe 2008). Furthermore, studies have shown that $3 \mathrm{D}$ environments where consumers have interactive product experiences can influence product knowledge, purchase intentions, and cause a more favorable brand attitude (Li et al. 2002; Suh and Lee 2005; Li et al. 2001; Suh and Chang 2006). As a result, the use of VR in marketing and education 
practices creates a great foundation to explore if Fair-trade coffee products can leverage this technology in order to impact consumer behaviour.

Virtual reality (VR) has been an emerging technology over the last decade, growing to new levels of sophistication. VR technology simulates advanced threedimensional (3D) humancomputer interaction by providing consumers with an immersive experience (visual, auditory, and haptic). Cooper (2017) describes VR as a growing retail trend where augmented reality (AR) thrusts consumers into a new world. VR will allow shoppers to discover new products and learn more about the ones they are already familiar with (Cooper, 2017).

VR goes as far back as 1838 with stereoscopic photos and viewers but, not until 1968, Dr. Ivan Sutherland and his student Bob Sproull created the first VR/AR headmounted display. In 1987, the term VR was coined by Jaron Lanier and his extensive research (Virtual Reality Society, 2017). The technology has garnered great interest from the research community and has seen much publication on its use in gaming and specialized applications such as, military, engineering, medical training (Abulrub, Attridge, \& Williams, 2011; Burdea, 2002; Janda et al., 2004; Sparrow, Harrison, Oakley, \& Keogh, 2018). Moreover, VR technology has been shown to educate consumers by superimposing educational information over real world views (The Economist, 2007; Thomasson, 2006), add value with the perceived accuracy and quality (Chhabra, 2005; Waitt, 2000) and involve relevant authority (Budruk et al., 2008;

Revilla \& Dodd, 2003). Finally, VR has shown tremendous growth in different aspects of marketing. Leveraging its technology in bricks and mortar retailing (Domina et al. 2012; Hassouneh and Brengman 2015) and exceptional growth in tourism marketing (Huang et al. 2016). 
With the increasing popularity and use of VR technologies, the cost of VR has dropped considerably. Mark Zuckerberg purchased Oculus in 2014 for 2 billion dollars and released the long-awaited Oculus Rift headset which was a considerable improvement (Luckerson, 2014; Castelvecchi, 2016). Now, many major players; Samsun, HTC, Sony, and Google are making large investments within AR/VR (Korolov, 2014; Ebert, 2015; Castelvecchi, 2016). Today, aspects of VR/AR can be adopted in a very feasible way. Inexpensive cardboard holders or very basic goggles can be purchased to leverage your smartphone's capability within the VR realm. Free platforms such as YouTube, Jaunt VR, and Within are readily available to the public to leverage movies, video clips, games, and advertisements. The worldwide AR/VR market size is forecast to grow 7.7X between 2018 and 2022 (Petrov, 2019), where 79\% of Generation Z considers VR as an important tool for adoption in the coming future (Burch, 2017).

In this thesis, I will begin by looking at consumer purchase intentions regarding Fairtrade coffee through the lenses of the Theory of Reasoned Action (TRA) and the context of Generation Z (Gen Z). A first analysis will allow me to outline, present, and test a model regarding Fair-trade coffee consumption in the scope of TRA. Additionally, a second analysis will leverage VR in an exploratory manner to see if this has an effect on the variables outlined in my conceptual model. Although VR's potential has grown and been discussed tremendously over the last decade, very little has been presented on the use of this tool to impact variables within consumer behaviour frameworks. This outlined gap in knowledge, VR's expected future growth, and the increasing interest from Generation $\mathrm{Z}$ form the motivation for this study.

The thesis will be organized as follows: research question, goals, and motivation behind this research. Followed by research design, methodology, and explaining in 
further detail the paradigm that forms the approach. Furthermore, I review the literature of ethical/sustainable consumption, Fair-trade, Gen Z, Theory of Reasoned Action, and virtual reality. Then, based on the foundation of Theory Reasoned Action (TRA), I present a series of hypotheses. Next, I test the proposed hypotheses and seek answers to the research question, which includes the methodology, results and discussion section. Finally, I summarize a general discussion of findings, research limitations, implications, and future research endeavours. 


\section{Chapter 2. Research Question, Goals, and Motivation}

The research questions for this thesis are as follows:

1. To what extent do Personal Values (Competence, Idealism), Knowledge of Fair-trade, and General Attitudes Towards Fair-trade (Skepticism, Concern) influence Attitudes towards Purchasing Fair-trade Coffee (Product interest and likeability, Price acceptability)?

2. To what extent do Attitudes towards Purchasing Fair-trade Coffee (Product interest and likeability, Price acceptability) and Subjective Norms influence Consumer Purchase Intention (Figure 1, Constructs)?"

The relevance of VR, as mentioned in the previous section, has grown noticeably in education/training and marketing purposes within the user experience. Furthermore, its rapid growth and development have made the technology increasingly more attainable and affordable to reach a wider audience. In contrast, sustainable movements such as "Fair-trade" have become a characteristic that Generation $\mathrm{Z}$ is increasingly willing to adopt. Moreover, there has been an international shift in willingness to pay for sustainable products. As a result, VR has positioned itself to be a very strong communication tool for social scientist and marketers to add value, communicate effective messages, and impact consumer behaviour. With this communication tool and specialty product, I set out to explore the following:

3. How does VR effect the variables in the proposed model (Figure 1) except Personal Values? 
Table 1: Constructs

\begin{tabular}{ll}
\hline Concept & Dimension/Construct \\
\hline Personal Values (Rokeach Value Scale) & $\begin{array}{l}\text { Competence } \\
\text { Idealism }\end{array}$ \\
\hline Knowledge of Fair-trade & Knowledge of Fair-trade \\
\hline General attitude towards Fair-trade & $\begin{array}{l}\text { Skepticism } \\
\text { Concern }\end{array}$ \\
\hline Attitudes toward Purchasing Fair-trade & $\begin{array}{l}\text { Product Interest and Likeability } \\
\text { Price Acceptability }\end{array}$ \\
Coffee & Subjective Norms \\
\hline Subjective Norms & \\
\hline
\end{tabular}

With the growing popularity and integration of VR/AR capabilities, one motivation of this research is to apply and investigate a new pertinent application of this tool. More so, to educate the population on sustainable practices and assist marketers in leveraging these products. The hope is that this immersive experience can bring education and awareness to sustainable practices by leverage social issues and, in turn, impact consumer behaviour.

This research contributes to the fields of TRA, ethical/sustainable consumption, Fair-trade, and the gap in knowledge on the increasing interest of ethical/sustainable products and VR from Gen Z. Additionally, VR's educational and marketing potential to impact consumer behaviour. While lots of research has been published on VR's education and training capabilities due to its stimulating nature and appeal to visual, auditory, and kinesthetic learning styles (Roussou, 2004; Garris et al., 2002; Ott \& Tavella, 2009; Leite et al, 2010) as well as its marketing potential (Domina et al. 2012; Hassouneh and Brengman 2015; Huang et al. 2016). To the best of my knowledge, nothing has ever been presented on VR/AR technology for the use of educational or marketing implications on ethical/sustainable products and its impact on consumer behaviour. Lastly, this research initiates a discussion on whether VR can positively effect variables within consumer behaviour frameworks. 


\section{Chapter 3. Research Design, Approach, Paradigms}

The goal of the illustrated exploratory research is to explain what extent Personal Values, Knowledge of Fair-trade, and General Attitudes Towards Fair-trade influence Attitudes towards Purchasing Fair-trade Coffee. As well as, Attitudes towards Purchasing Fair-trade Coffee and Subjective Norms influence Consumer Purchase Intentions. Additionally, how does VR effect these variables except for Personal Values? Dr. Norman Blaikie, the author of Designing Social Research, discusses deductive research strategy as, "the aim of the deductive research strategy is to find an explanation for an association between two concepts by proposing a theory, the relevance of which can be tested" (Blaikie, 2010, P.85). Furthermore, he summarizes that the theory can either be borrowed or invented to then generate hypotheses and then test with data to provide explanations and conclusions (Blaikie, 2010). This deductive approach applies to the outlined research as I investigate VR's effect on the variables presented in consumer's purchase intention towards Fair-trade coffee. The research and hypotheses follow the framework of the Theory of Reasoned Action (TRA), which will be discussed in more detail in the following chapters.

Elaine Guba defines a paradigm as, "Simply a belief system (or theory) that guides the way we do things, or more formally establishes a set of practices. This can range from thought patterns to action" (Guba, 1990, p. 105). The research is positioned under the philosophical paradigm of positivism. Dr. Norman Blaikie defines this as, "positivism regards reality as consisting of discrete events that can be observed by the human senses. The only knowledge of this reality that is acceptable is that which is derived from experience" (Blaikie, 2010). The term originated from August Comte in the $19^{\text {th }}$ century ultimately describing an approach where the "study of society" relies explicitly on scientific evidence (experiments and statistics) to divulge 
the true nature of how society operates (Serva, 2016). According to John Creswell, "this paradigm helps positivist researchers clearly understand the objects by empirical tests and methods as sampling, measurement, questionnaire, and focus group discussion. This suggests that insights provided by positivist researchers may have high quality standard of validity and reliability" (Creswell, 2007, p.303). In turn, this quantitative research is positioned under a positivist research approach. 


\section{Chapter 4. Literature Review and Theoretical Background}

\section{Ethical/Sustainable consumption}

The increasing knowledge among consumers has shifted purchase decisions demonstrating their commitment towards ethical values (Berry and McEachern 2005; Nicholls 2002). Consumers making purchase decisions based on values embracing environmental sustainability and/or social justice has created a niche market of customers widely known as ethical consumers (Cherrier 2007; Harrison et al. 2005; Newholm and Shaw 2007). The definition of an ethical consumer (sometimes also called a political consumer) according to Dr. Michele Micheletti is:

"Actions by people who make choices among producers and products with the goal of changing objectionable institutional or market practices. Their choices are based on attitudes and values regarding issues of justice, fairness, or noneconomic issues that concern personal and family well-being and ethical or political assessment of favorable and unfavorable business and government practice" (Micheletti, 2003, p.2).

The definition provided by Micheletti (2003) indicates that ethical consumers consider factors beyond the material use of the product (e.g., environmental, health, and social concerns), regardless of whether those are personal, societal, or a combination of both. Micheletti (2003, p.2) also adds an additional factor, "the goal of changing objectionable institutional or market practices". The act of consuming "ethical products" has social change motivations and seeks to transform the current capitalist system (e.g. Micheletti et al., 2004; Stolle et al., 2006).

Ethical consumers are concerned about shifting their consumption to goods and services that are consistent with their ethical concerns. In today's capitalistic society, it is very unlikely that ethical consumers can take the approach of anti-consumerism and reject consumption 
completely (Zavestoski \& Stephen, 2002). Therefore, individual ethical consumers may adopt one or more behavioural approaches including; downshifting, voluntary simplicity, and/or more sustainable levels of consumption through the selection of more ethical alternatives (Shaw \& Newholm, 2002). Voluntary simplicity is a recognition that Western Society consumption habits are degrading the earth. As a result, people choosing to live in this niche market choose to reduce their consumption. Downshifting, simply meaning to change or lower, is a variation of voluntary simplicity. Although both groups voluntarily simplify their consumption, ethical simplifiers are distinguished from downshifters by their concerns about environmental, social, and animal welfare issues (Shaw \& Newholm, 2002). People who choose voluntary simplistic lifestyles have been shown to have more ethical consideration of the environmental and the social impact of their consumption choices. Additionally, these types of lifestyles are also encouraged to boycott and make positive purchases, such as seeking out Fair-trade products and favouring small stores or local produce (Shaw \& Newholm, 2002).

On the other hand, sustainable consumption has been assessed as the decision-making process that takes the consumer's social responsibility into consideration as well as their individual needs and wants (Meulenber, 2003). Ethical consumers feel responsible towards society and attempt to rectify the unethical behaviour by corporations by altering the purchase behaviours (De Pelsmacker et al., 2003). Although the primary factors affecting purchase behaviours remain price, quality, convenience, and brand recognition (Carrigan \& Attalla, 2001; Weatherell et al., 2003), only a small minority of consumers highly value ethical consideration. Gender has been seen to not influence ethical decision-making (Tsalikis \& Ortis-Buonafina, 1990; Sikula \& Costa, 1994; MORI, 2000). While demographics, often used as main market segmentation variables, are not significant in defining socially responsible consumers because 
the ethical concern and issue have become widespread (Roberts, 1995; Diamantopoulos et al., 2003). Studies have suggested that psychological variable like attitudes, beliefs, and subjective norms independently are good indications that predict purchase intention for sustainable products (Robinson \& Smith, 2002). In turn, showing that the literature suggests that beliefs, attitudes, and intentions positively influence ethical/sustainable consumption.

\section{Fair-Trade}

Sustainable and ethical consumers feel responsible towards society and attempt to rectify any unethical behaviours done by corporations. These unethical behaviours can include environmental, social, and animal welfare issues. Fair-trade products are just one of the items that these groups of individuals strive to get more consumers to purchase in hopes of reducing poverty, encouraging environmentally friendly production methods, and safeguarding humane working conditions.

Fair-trade is defined as the notion of fostering trading partnerships between producers and consumers in order to build sustainable linkages (Jaffee et al., 2004). Fair-trade must follow the notions of; fair working wages, safe/clean and regulated work spaces, empowerment of artisans, sustainable business practices, fostering of well-being, overarching push for political and social justice, and growing equitable trade (Global Fai-Trade Enterprise, 2019; Littrell and Dickson, 1999; Mori, 2000).). Creating these relationships have garnished Fair-trade workers a $53 \%$ increase in return on their products (Global Fair-Trade Enterprise, 2019). Demand for Fairtrade products has seen a huge shift over recent years. Global sales of Fair-trade product increased $16 \%$ in 2 years to reach U.S\$6.2 billion (Fairtrade International, 2018). Where coffee, representing the largest category, increased 3\% during the same period (Fairtrade International, 2018). Furthermore, Nielsen's 2016 poll in over 60 countries saw $66 \%$ percent of global 
consumers willing to pay more for sustainable goods versus a whopping 73 percent of Gen $\mathrm{Z}$ willing to do the same (Nielsen, 2016).

Many studies have illustrated the overall commodity production and market of Fair-trade products (e.g., Jaffee et al., 2004; Murray et al., 2006). Other areas have focused on the societal dilemmas and improvements Fair-trade have brought to developing countries (Murray et al., 2006; Utting-Chammoro, 2005). Much research has been presented on willingness to pay more for Fair-trade products around the globe (CRCConsommation, 1998; MORI, 2000; Loureiro, McCluskey and Mittelhammer, 2002). Notably, a study done in Belgium reported that consumers are willing to pay on average 10\% more for Fair-trade labelled product (De Pelsmacker et al., 2005). Similarly, a study done in Italy found that consumers are willing to pay $9 \%$ more for Fairtrade products (Maietta, 2003). In England, Fair-trade was outlined as the most important ethical concern to consumers (Shaw \& Clarke, 1999). Moreover, many studies have found that ethical consumers are people with relatively high income, education, and social status (Roberts, 1996; Carrigan and Attalla, 2001; Maignan and Ferrell, 2001; De Pelsmacker, Driessen and Rayp, 2005) and is not influenced by gender (e.g. Tsalikis and Ortiz-Buonafina, 1990; Sikula and Costa, 1994; Mori, 2000). In turn, demographics alone are not enough to define ethical consumers. In contrast, research suggests that personal values, knowledge, and attitudes towards Fair-trade appear to have a significant impact on purchase intention (Del Pelsmacker \& Janssens, 2006; Ma, Littrell, \& Niehm, 2012).

A large issue represented in the literature is the attitudes to information on ethical Fairtrade issues and products (e.g. Roberts, 1996; Wessels, Johnston and Donath, 1999; Carrigan and Attalla, 2001; Maignan and Ferrell, 2004; Nilsson, Tunçer and Thidell, 2004). With 1,599 Fairtrade labels worldwide (Fairtrade International, 2018), many labelling programs, certifications, 
and organizations confuse consumers with different organizational criteria and standards. Literature has presented findings of customer confusion, lack of credibility and erosion of customer confidence (Salzhauer, 1991; Teisl, Roe and Levy, 1999; Nilsson, Tunçer and Thidell, 2004). In contrast, lots of information of low quality or minimal information of high quality has influenced the consumer that ethical purchases will make a difference (Titus and Bradford, 1996; Carrigan and Attalla, 2001). In any case, the overall perception of consumers' information levels on "Fair-trade" will play a factor in the developmental role of the ethical buying behaviour,

\section{Generation Z}

Generation $\mathrm{Z}$ accounts for 32 percent of the global population (7.7 billion), slightly ahead of the millennials at 31.5 percent (Bloomberg, 2019). Forbes describes Gen $Z$ consumption patterns when it states, "Gen $\mathrm{Z}$ is already on track to become the largest generation of consumers by the year 2020, and they account for $\$ 29$ to $\$ 143$ billion in direct spending" (Forbes, 2019). Moreover, Gen $\mathrm{Z}$ is considered as one of the most ethical/sustainable sensitive cohorts ever. Gen $\mathrm{Z}$ is willing to spend as much as 10 to 15 percent more on sustainable products. Comparatively, 73 percent of Gen Z's would pay more for a sustainable product, compared to just 51 percent of Baby Boomers (Forbes, 2019).

Wood (2013) defined four trends to describe Gen $Z$ as consumers: 1) An interest in new technologies, 2) An insistence on ease of use, 3) A desire to feel safe, and 4) A desire to temporarily escape the realities they face. They are a generation that is highly educated and born into a digital age which accelerates technology adoption. They put a large emphasis on political, social, economic, and technological change where consumers are less brand loyal and care more about the experience (Schlossberg, 2016). 
Literature has outlined that consumers' knowledge, awareness, and favourable attitudes concerning Fair-trade products and ethical concerns did not necessarily lead to purchase intentions among certain younger sample group. (Nicholls \& Lee 2006). Additionally, research from Ma et al, (2012) suggests that "findings from previous Fair-trade studies that were based on other generational cohorts may not be applicable to the young consumer groups who have some distinctive consumption behaviours" (Ma et al, 2012, p.46). That said, Schlossberg (2006) defines the challenge with Gen $Z$ as, "Generation $Z$ is a challenge, since it appears that they behave differently to earlier generations and this behavior can lead to changes in consumer behavior" (Schlossberg, 2016, p.6). Altogether, representing a gap in Gen Z's consumer behavior as it differs from previous generational cohorts.

\section{Theory of Reasoned Action}

Theory of Reasoned Action (TRA) is the overarching theoretical framework that guides the structure of the proposed model of this research. It explains the relationship between attitudes and behaviour within human action (Hahn, 2018). The primary purpose of the TRA and its application for this present study is to understand an individual's voluntary behaviour by examining their underlying motivations to perform that action (Hale et al., 2002). As a result, its explanation excludes behaviours that are spontaneous, impulsive, habitual, the result of craving, or mindless (Bentler \& Speckart, 1979; Langer, 1989). Such behaviours are concluded not to be voluntary and are not determined to be a conscious decision by the consumer.

TRA suggests that the most influential predictor of a person's voluntary behaviour is one's behavioural intention. Behavioural intention is the result of both one's attitudes and one's subjective norms (Davis et al., 1989, p. 983). "Attitude" is determined beliefs about consequences and the likelihood and severity of those consequences. On the other hand, 
"Subjective Norms" are determined by normative beliefs (what others think one should do) and our motivation to comply with those normative beliefs. (Trafimow, 2009). This "behavioural intention" suggests that a specific behaviour will lead to a specific outcome. As a result, understanding consumer's behavioural intentions will allow researchers to influence the behaviour of consumers (Fishbein and Ajzen, 1975, p. 288).

Figure 1: Theory Reasoned Action (TRA) Framework

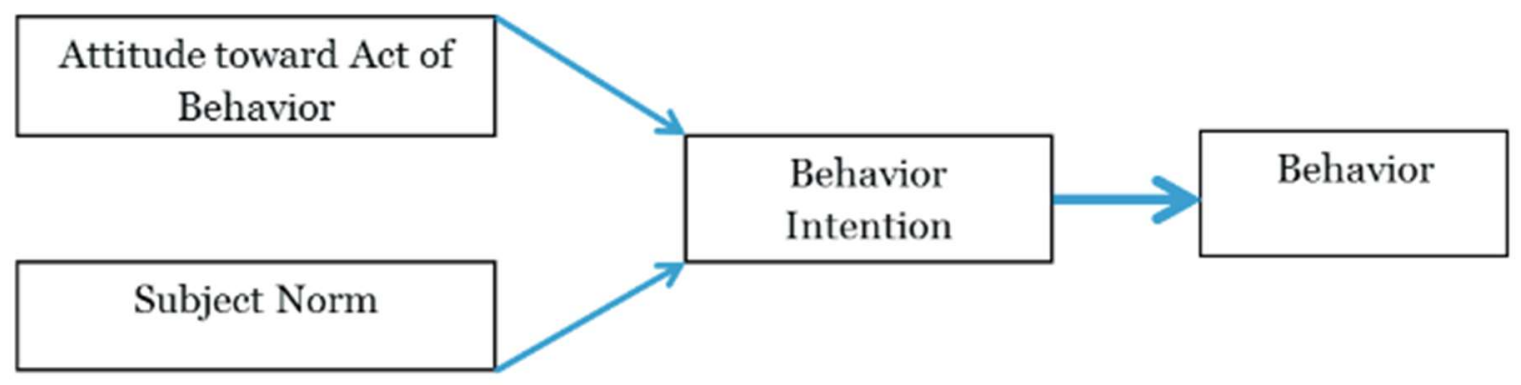

\section{$B I=(A B) W 1+(S N) W 2$ \\ $B I=$ behavioural intention $(A B)=$ one's attitude toward performing the behaviour $W=$ empirically derived weights $S N=$ one's subjective norm related to performing the behaviour}

TRA suggests that stronger intentions lead to increased effort to perform the behaviour, which also increases the likelihood for the behaviour to be performed (Trafimow, 2009). Much research has claimed that individual internalized ethical ruling, which reflects personal beliefs, has been found to improve prediction of intention, attitudes, and subjective norms (Gorsuch \& Ortberg 1983; Raats, Shepherd and Sparks, 1995). The context of TRA often looks at the intention regarding self-interest concerns and behaviours, but ethical and Fair-trade contexts are centred on the interests of others (Shaw, Shiu, \& Clarke, 2000). 
TRA's application has been beneficial in many studies regarding the determinant of human social behaviour (Ajzen, 2001; Davis, Ajzen, Saunders, \& Williams, 2002; Kidwell \& Jewell, 2003; Lunday \& Barry, 2004), in particular, consumer behavior (Ajzen, 2001; Davis, Ajzen, Saunders, \& Williams, 2002; Kidwell \& Jewell, 2003; Lunday \& Barry, 2004). Although TRA has been often shown to predict intention, it is not necessarily indicative of consumer behaviour (Shaw, D., Shiu, E., \& Clarke 2000, I.; Boyd \& Wandersman 1991; Vallerand et al. 1992). Much research has been presented showing that consumer perception and attitudes clearly influence behaviour (Ferrell \& Gresham 1985; Hunt \& Vitell 1993; Shaw \& Clarke 1999; Vitell, Singhapakdi, \& Thomas 2001). On the other hand, attitudes and intention alone are not indicative of actual buyer intention in social marketing (Cobb-Walgren \& Ruble 1995; Shaw \& Clarke,1995). In turn, the inclusion of immersive technology like VR may prove as a beneficial tool to help connect purchase intentions and actual purchase behaviours.

Attitudes toward purchasing Fair-trade Coffee

According to Fishbein (1967), attitudes refers to, "learned predisposition to respond to an object or class of objects in a consistently favorable or unfavorable way" (Fishbein, 1967, p.389). In simpler terms, a person's positive or negative feeling of performing that behaviour. Vast literature has been presented on attitudes being a significant determinant on purchase intention regarding ethical consumption. Notably, shopping for organic products (e.g. Aertsens et al., 2009; Shaw and Shiu, 2002; Sparks and Shepherd, 1992; Tarkiainen and Sundqvist, 2005) as well as shopping for food-specific Fair-trade products (e.g. Ozcaglar-Toulouse et al., 2006; Shaw, 2005). Literature also suggests that attitudes to information lead to interest in purchasing ethical or Fair-trade product (Roberts, 1996; Wessels, Johnston and Donath, 1999; Carriganand Attalla, 2001; Maignan and Ferrell, 2004; Nilsson). Shaw and Shiu (2002) found attitudes and 
perceived control as a significant determinant factor of purchase intention with consumers in Fair-trade grocery shopping. Similar result by Ozcaglar-Toulouse et al. (2006) suggested attitudes and subjective norms explained significantly purchase intentions of "never" or "rarely" Fair-trade shoppers, while attitudes influenced the purchase intentions of regular shoppers. Cranfield et al. (2010) found that price was the most important attribute to consumers regarding Fair-trade coffee consumption. All value groups concluded that the price of Fair-trade coffee is too high. Comparatively, other literature suggests that consumers are willing to pay premium prices for products labelled as FT (Reinstein and Song, 2012; Trudel and Cotte, 2009).

I adopted dimensions from De Pelsmacker et al. (2005) research on consumer values and Fair-trade beliefs on attitudes and buying behaviour towards Fair-trade coffee consumers. A literature review and four focus groups were conducted where two dimensions were established to describe attitudes towards purchasing Fair-trade coffee. De Pelsmacker et al. (2005) defines these constructs as "product interest reflected the idea that respondents were interested in Fairtrade products. Liking for products dealt with the belief that Fair-trade products are healthier, tastier and of better quality than "normal" products" (De Pelsmacker et al., 2005, P.57). Price acceptability, reflected the respondents' level of acceptance or disagreement to Fair-trade coffee prices. "Product interest and likeability" as well "price acceptability" form the dimensions of attitudes towards purchasing Fair-trade coffee. Thus, the following hypotheses are put forward: 
Figure 2: Attitudes and Subjective Norms

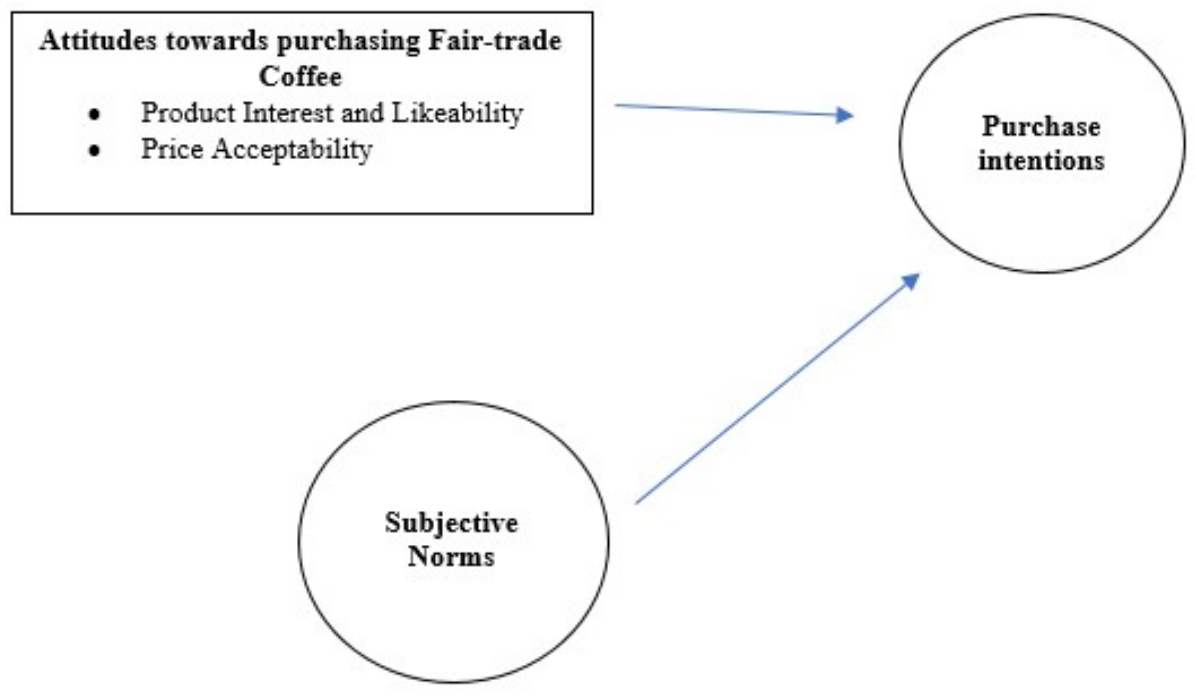

H1a: Product Interest and Likeability will have a significant influence on Purchase Intention

H1b: Price Acceptability will have a significant influence on Purchase Intention

\section{Subjective Norms}

Subjective norms are defined as, "the perceived social pressure to perform or not to perform the behavior" (Ajzen 1991, p. 188). This can be described as an individual's perception or opinion about what others believe the individual should do (Finlay et al., 1999). These pressures can come from family, friends, colleague or classmates. This perception or opinion is considered as one's normative belief which, in the context of TRA, is often multiplied by its motivation to comply (Ajzen \& Fishbein, 1972). Many conclusions from literature have found Subjective norms to be statistically significant on the purchase of Fair-trade products (De Leeuw et al. 2014; Ozcaglar-Toulouse et al. 2006; Tarkiainen and Sundqvist 2005). As mentioned above, results by Ozcaglar-Toulouse et al. (2006) suggested attitudes and subjective norms explained significantly purchase intentions of "never" or "rarely' FT shoppers. Additionally, 
research shown by Oberseder et al. (2011) suggests that an important variable to integrate within corporate social responsibility (CSR) consumer behaviour is peer influence, which can be associated to subjective norms. Thus, the following hypothesis is put forward:

H2: Subjective Norms will have a significant influence on purchase intention.

Personal Beliefs

Personal beliefs or values are described as the things that are important to people regarding the characteristics and behaviours that motivate and guide their decisions (Blackman, 2018). Many interpretations have been presented in literature to describe these beliefs. Anderson and Cumming (1972) have found that dogmatism, conservatism, status consciousness, cosmopolitanism, personal competence, and alienation are directly related to ethical consumer behaviour. Furthermore, Littrell and Dickson (1999) attributed altruism, equality, world peace and a beautiful and environmentally secure world to cultural Fair-trade products. De Pelsmacker et al., (2007) concluded that idealism and hedonic predisposition were personal values determinant to Fair-trade buying behaviour. Finally, Kim et al., (2010) argued that Fair-trade consumption values primarily determine consumer loyalty toward FT brand which in turn positively affect attitudes and purchasing behaviour. One of the best tools to measure an individual's personal values is the Rokeach Value Scale (RVS) (Rokeach, 1973). The scale consists of 18 terminal values and 18 instrumental values where respondents rank from 1 "Very Unimportant" to 7 "Very Important". I adopted dimensions and Rokeach value scale from De Pelsmacker et al. (2005) where four dimensions were outlined; Competence, Idealism, Sense of Public Responsibility, and Being Sympathetic. Competence represents individual values of, independent, clean, forgiving, and social recognition. While Idealism represents a world at peace, equality, courageous, national security, and a world of beauty. Sense of Public 
Responsibility represents polite, responsible, and obedient. Finally, Being Sympathetic represents helpful and forgiving.

Someone who is competent is defined as having the ability to do something successfully or efficiently. Competence, in this case, will be a significant predictor of product interest and likeability and price acceptability because of the ability to successfully define and understand the concept of Fair-trade. Someone who is idealistic is envisioning or pursuing ideas that represent the ideal and perfect manner. Idealism, in this case, will be a significant predictor product interest and likeability and price acceptability because the vision of an ideal/perfect world should include Fair-trade. Sense of public responsibility outlines one's duties or actions encouraging the public. Sense of public responsibility, in this case, will be a significant predictor of product interest and likeability and price acceptability because it encourages ethical/sustainable consumption to the public. Being sympathetic represents ones feelings or actions of being sorry. Being sympathetic, in this case, will be a significant predictor of product interest and likeability and price acceptability because it outlines respondent's emotions and actions of feeling sorry towards the sustainability crisis.

Thus, the following hypotheses are put forward:

H3a: Competence will have a significant influence on Product Interest and Likeability H3b: Competence will have a significant influence on Price Acceptability H4a: Idealism will have a significant influence on Product Interest and Likeability H4b: Idealism will be a significant influence on Price Acceptability H5a: Sense of Public Responsibility will have a significant influence on Product Interest and Likeability 
H5b: Sense of Public Responsibility will have a significant influence on Product Interest and Likeability

H6a: Being Sympathetic will have a significant influence on Product Interest and

\section{Likeability}

H6a: Being Sympathetic will have a significant influence on Price Acceptability

Knowledge of Fair-trade

Fair-trade, in brief, advocates for payment of fair working wages, safe, clean and regulated work spaces, empowerment of artisans, sustainable business practices, fostering of well-being, overarching push for political and social justice, and growing equitable trade (Littrell and Dickson, 1999; Mori, 2000). Fair-trade, being defined by such a breadth of different criteria, makes knowledge an important factor. Literature has outlined knowledge as an important factor to impact our belief systems, attitudes, and purchase intentions (Del Pelsmacker \& Janssens, 2005; Ma, Littrell, \& Niehm, 2012). DePelsmacker, Patrick, \& Janssens (2007) found that more people have knowledge about the issue of Fair-trade, led to an increase in attitudes towards purchasing Fair-trade and overall purchase intentions. Furthermore, research done by d'Astous, Alain, \& Mathieu (2008) on inciting consumers to buy Fairly-traded products suggests that more information consumers are given, leads to a larger amount spent on purchases. Finally, Lee (2011) suggests that concrete sustainability knowledge was a significant predictor in behaviour associated with sustainable consumption. Knowledge of Fair-trade was adopted from De Pelsmacker et al. (2005) where a literature review and four focus groups were conducted. De Pelsmacker et al. (2005) define knowledge of Fair-trade as "Respondents with high scores on the knowledge construct demonstrated high levels of competence in accurately defining Fair-trade" (De Pelsmacker et al., 2005, p.56). Thus, the following hypotheses are put forward: 
H7a: Knowledge of Fair-trade will have a significant influence on Product Interest and Likeability

H7b: Knowledge of Fair-trade will have a significant influence on Price Acceptability

\section{General Attitudes Towards Fair-trade}

Consumers have had an increasingly difficult time in their attitudes regarding Fair-trade products. (Roberts, 1996; Wessels, Johnston and Donath, 1999; Carrigan and Attalla, 2001; Maignan and Ferrell, 2004; Nilsson, Tunçer and Thidell, 2004). Confusion, lack of credibility, and erosion of customer confidence are all factors which research has presented the effect on labelling certification programs and organizations tied to Fair-trade (Salzhauer, 1991; Teisl, Roe and Levy, 1999; Nilsson, Tunçer and Thidell, 2004). Research from Pedragal et al. (2011) suggests that $13 \%$ of the Western population have a negative image of Fair-trade and $42 \%$ acknowledge that they "do not know much about it". Additionally, Research from Tuncer and Thidell (2004) concluded that competing labelling programs, certifications, and organizations tied to Fair-trade confuse costumers, undermine credibility, and leave doubt with consumers.

General attitudes towards Fair-trade was adopted from De Pelsmacker et al. (2005), where a literature review and four focus groups identified two constructs; Skepticism and concern. De Pelsmacker et al. (2005) describe skepticism when they state, "skepticism, reflecting the disbelief of respondents concerning the concept of Fair-trade, because it is too close to the notions of charity and colonialism, or because they did not believe that Fair-trade can work in this world" (De Pelsmacker et al., 2005, p.57). The second construct was defined as "concern, indicating concern about the Fair-trade issue in general" (De Pelsmacke et al., 2005, p.57). Thus, the following hypotheses are put forward:

H8a: Skepticism will have a significant influence on Product Interest and Likeability 
H8b: Skepticism will have a significant influence on Price Acceptability

H9a: Concern will have a significant influence on Product Interest and Likeability

H9b: Concern will have a significant influence on Price Acceptability

\section{Virtual Reality}

3D environments or virtual reality can be used to gain knowledge and educate consumers on Fair-trade products. As a result, this can help increase brand/product awareness and overall consumer perception of the Fair-trade industry. Using an immersive platform, such as virtual reality, has been proven to positively affect product knowledge, purchase intentions, and cause a more favourable brand attitude (Li et al. 2002; Suh and Lee 2005; Li et al. 2001; Suh and Chang 2006)

Virtual reality (VR) began in the 1960s by introducing the multisensory driving experience to consumers through the game 'Sensorama' (Najafipour et al., 2014; Stein, 2016). Throughout the 1980s and 1990s, virtual reality grew in business settings through the delivery of simulators (Lin et al., 2014). It wasn't until 2016 that virtual reality expanded to the mass market when Oculus Rift introduced higher quality imaging and better functionality (Yucel \& Edgell, 2015; Rebenitsch \& Owen, 2016; Stein, 2016). Before the innovation of Oculus Rift, many of the devices in the market were not as developed and thus not as appealing to consumers (Rebenitsch \& Owen, 2016; Stein, 2016). Although increasing in popularity with consumers and businesses, VR's initial high price disrupted the quick adoption for many (Blümel et al. 2009; Germani et al., 2012; Xia et al., 2013; Grabowski \& Jankowski, 2015; Stein, 2016). The Oculus Rift and other similar head-mounted display devices ranged from $\$ 599$ to $\$ 999$. However, cheaper alternatives were soon introduced to the market by Google and Samsung. This included 3D compatible technology for one's smartphone ranging from $\$ 5$ to $\$ 99$ (Google Cardboard, 
2017; Oculus, 2017). It's clear that VR has numerous applications across a multitude of markets at an increasingly affordable price. A report from Goldman Sachs (2016) forecasts the market for VR to reach $\$ 65$ billion in revenue by 2025 . The report indicates nine different markets (Retail estimated to be a 1.6-billion-dollar market with 32 million users) are expected to be disrupted by VR in the next six years (Goldman Sachs, 2016).

VR is a simulated 3D environment in which people become immersed (Wexelblat, 1993). VR can be classified into two separate categories depending on the extent of someone's immersion; immersive VR and non-immersive VR (Mills and Noyes 1999). In immersive VR, like the present study, with the help of head-mounted technology users are submerged in a 3D environment. Comparatively, non-immersive VR is most commonly observed through a limited desktop monitor and what they hear from speakers. Furthermore, VR elevates the senses in 3 important factors; immersion, interactivity, and presence (Bhatt, 2004; Walsh, 2002). Immersion can be represented as the user's sense of being isolated from the real world and stimulated by the virtual world (Witmer \& Singer, 1998). Interactivity can be represented as the user's ability to participate and modify content within VR environments in real-time (Steuer, 1992). Finally, presence can be represented as the subjective experience of being in one place/environment, even though physically situated in another (Witmer \& Singer, 1998). Biocca et al. (2001) suggests that VR successfully establishes the feeling of presence while interacting with products in a 3D environment. Additionally, Winn (1993) found that knowledge gets constructed through the interactivity created through virtual environments. VR's interactive nature through immersion and presence may assist in the knowledge building process.

VR provides its users with high media richness and interactivity, which as a result has been proven to generate compelling feelings of telepresence. Telepresence is the subjective 
feeling of "being there". (Biocca 1997; Klein 2003). High media richness is measured by the sensory depth and breadth of an interface (Steuer 1992). Depth refers to the quality of information while breadth refers to the number of sensory dimensions simultaneously presented. Immersive VR increases a user's sensory depth in the visual sense, especially with its high interactive ability to zoom and rotate 3D objects compared to non-immersive VR which creates only 2D static images (Klein 2003). This interactive function offers a high level of control engaging the user through active learning, rather than passive, giving every user the ability to adjust any kind of information to suit their individual needs (Pimentel and Teixeira 1994, pp. 2021). Through sensory stimuli conveyed by the immersive VR technology, users can create the perceptual illusion of being present and highly engaged in a virtual environment, while they are in retrospect physically present in another place (Biocca 1997).

Overall, the visual aspect of VR is generally the most important, which in turn means it has developed the quickest over the years (Gutierrez et al., 2008). This has generated the notion of Virtual Environment (VE) where people immerse and find themselves in a new environment (Mennecke, Terando, Janvrin, \& Dilla, 2007; Stangl \& Weismayer, 2008). VR is a rapidly enhancing technology which has been applied more frequently in simulations, entertainment, design, education, and marketing (Guttentag, 2009). Although little research has been presented on VR as a marketing tool for specialty products, it has had tremendous success in tourism marketing. VR has created what we define as information and communication technologies (ICT's) and etourism (Buhalis \& Law, 2008; Grønflaten, 2009; Najafipour et al., 2014).

VR has been recognized as an educational tool among many teaching professionals (Jacobson, Kelley, Ellis, \& Seethaller, 2005). It creates an environment where research has shown new methods of visualization and presentation, excitement and eagerness, and less focus 
on the aspect of "time" (Pantelidis, 1995; Mantovani, 2001). A recent survey expressed that $83 \%$ of teachers acknowledged that VR can improve learning outcomes and increase understanding (Bolton, 2016). The technology has been shown to be a great tool to communicate large amounts of information as it leverages the user's natural spatial perception abilities (Jacobson \& Holden, 2005, p. 2). Furthermore, the feeling of presence, entertainment, and most important interactivity have all led to positive educational results (Jacobson \& Holden, 2005; Mikropoulos, 2006;

Roussou, 2004; Roussou et al., 2006)

The literature has presented information which VR has seen to educate, market, and create value with its media richness, presence, interactive, and immersive qualities. Regarding the effect of VR in the context of this study, the following research question is put forward:

RQ: How does VR effect the variables in the proposed model except Personal Values? 


\section{Conceptual Model}

The presented constructs in the scope of TRA has generated the conceptual model for this research:

Figure 3: Proposed Model

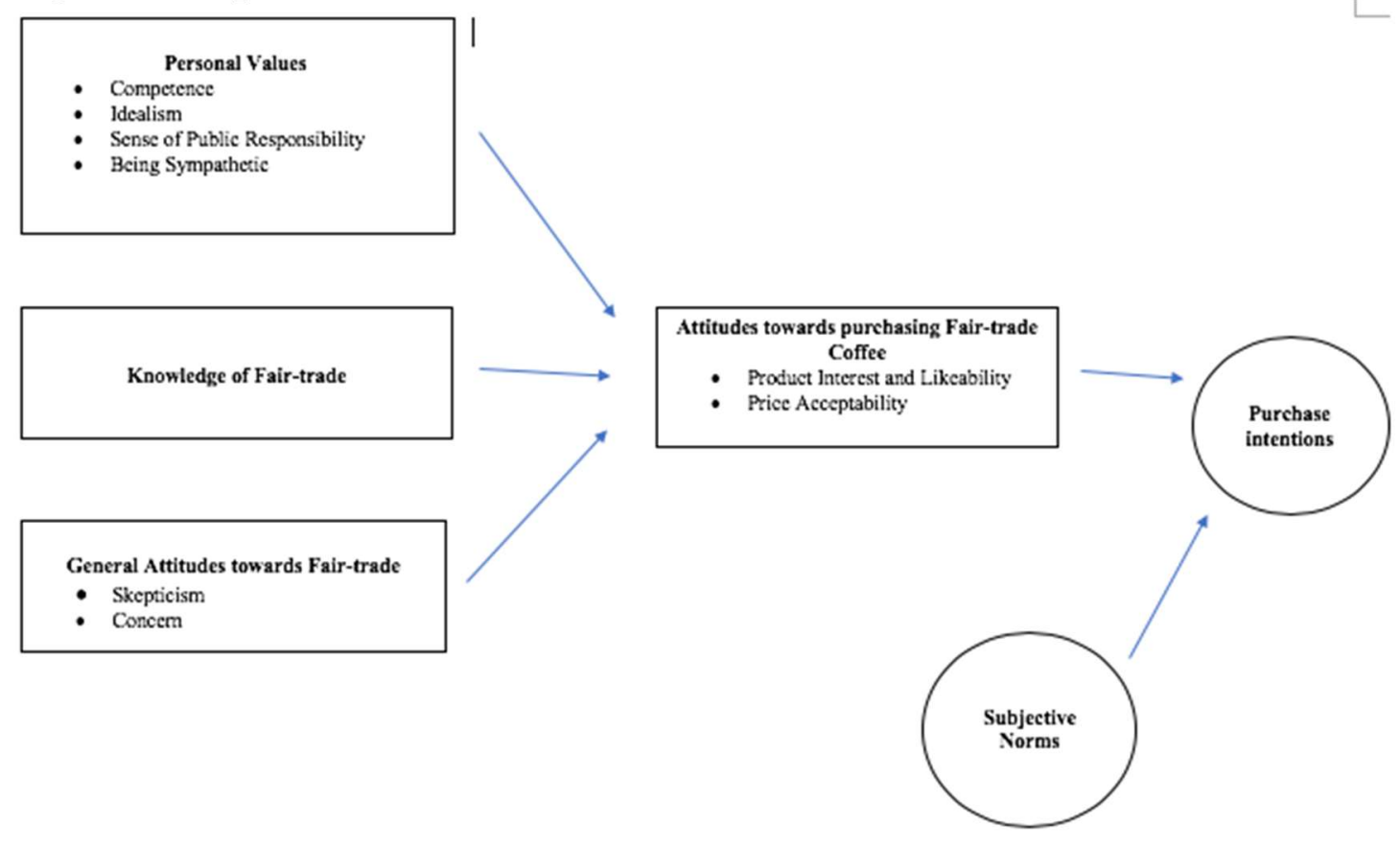

Summary of Hypotheses

Table 2: Summary of hypotheses

\begin{tabular}{l}
\hline Hypotheses \\
\hline H1a: Product Interest and Likeability will be a significant predictor of purchase intention \\
\hline H1b: Price Acceptability will be significant a predictor of purchase intention \\
\hline H2: Subjective Norms will be a significant predictor of purchase intention. \\
\hline H3a: Competence will be a significant predictor of Product Interest and Likeability \\
\hline H3b: Competence will be a significant predictor of Price Acceptability \\
\hline H4a: Idealism will be a significant predictor of Product Interest and Likeability \\
\hline H4b: Idealism will be a significant predictor of Price Acceptability \\
\hline H5a: Sense of Public Responsibility will be a significant predictor of Product Interest and \\
Likeability \\
\hline H5b: Sense of Public Responsibility will be a significant predictor of Product Interest and \\
Likeability \\
\hline H6a: Being Sympathetic will be a significant predictor of Product Interest and Likeability \\
\hline H6b: Being Sympathetic will be a significant predictor of Price Acceptability \\
\hline H7a: Knowledge of Fair-trade will be a significant predictor of Product Interest and \\
Likeability
\end{tabular}


H7b: Knowledge of Fair-trade will be a significant predictor of Price Acceptability

H8a: Skepticism will be a significant predictor of Product Interest and Likeability

H8b: Skepticism will be a significant predictor of Price Acceptability

H9a: Concern will be a significant predictor of Product Interest and Likeability

H9b: Concern will be a significant predictor of Price Acceptability 


\section{Chapter 5. Methodology}

\section{Instrument}

The instrument for this research was primarily adopted from De Pelsmacker and Janssens (2005) which outlined a model for Fair-trade buying behaviour based on product-specific attitudes (Figure 6). Slight modifications and inclusions where added from d'Astous et al. (2008) and Ajzen, I. (2001) to outline the scope of TRA. All items were measured using a seven-point Likert scale from "Strongly Disagree to Strongly Agree" or "Very Unimportant to Very Important" as well as randomized to maintain validity. The questionnaire included demographic questions which outlined; gender, age, level of education, household income, and employment status.

Table 3: Scale Items

\begin{tabular}{|c|c|c|}
\hline Construct & Items & Source \\
\hline $\begin{array}{c}\text { Personal } \\
\text { Values } \\
\text { (Rokeach } \\
\text { Value Scale) }\end{array}$ & $\begin{array}{l}\text { 1. A World at Peace (a world free of war and conflict) } \\
\text { 2. Intellectual (intelligent and reflective) } \\
\text { 3. Courageous (standing up for your beliefs) } \\
\text { 4. Helpful (working for the welfare of others) } \\
\text { 5. Loyal (faithful to friends or the group) } \\
\text { 6. A Comfortable Life (a prosperous life) } \\
\text { 7. Obedient (dutiful, respectful) } \\
\text { 8. Mature Love (Sexual and spiritual intimacy) } \\
\text { 9. A Sense of Accomplishment (a lasting contribution) } \\
\text { 10. Imaginative (daring and creative) } \\
\text { 11. Equality (brotherhood and equal opportunity for all) } \\
\text { 12. Pleasure (an enjoyable, leisurely life) } \\
\text { 13. Ambitious (hardworking and aspiring) } \\
\text { 14. Responsible (dependable and reliable) } \\
\text { 15. Family Security (taking care of loved ones) } \\
\text { 16. National Security (protection from attack) } \\
\text { 17. Self-respect (self-esteem) } \\
\text { 18. An exciting Life (a stimulating, active life) } \\
\text { 19. Inner Harmony (Freedom from inner conflict) } \\
\text { 20. Salvation (saved; eternal life) } \\
\text { 21. Health (physical and mental well-being) } \\
\text { 22. A world of Beauty (beauty of nature and the arts) } \\
\text { 23. True Friendship (close companionship) } \\
\text { 24. Freedom (independence and free choice) }\end{array}$ & $\begin{array}{l}\text { Rokeach 1973; Munson } \\
\text { and Mclntyre, 1979; } \\
\text { Finegan 1994, Muson and } \\
\text { Posner, 1980; Fritzsche } \\
\text { 1995; De Pelsmacker and } \\
\text { Janssens, } 2005\end{array}$ \\
\hline
\end{tabular}




\begin{tabular}{|c|c|c|}
\hline & $\begin{array}{l}\text { 25. Logical (consistent, rational) } \\
\text { 26. Self-controlled (Restrained, self-disciplined) } \\
\text { 27. Honest (sincere and truthful) } \\
\text { 28. Capable (competent, effective) } \\
\text { 29. Polite (courteous and well-mannered) } \\
\text { 30. Social Recognition (respect and admiration) } \\
\text { 31. Clean (neat and tidy) } \\
\text { 32. Forgiving (willing to pardon others) } \\
\text { 33. Broad-minded (open-minded) } \\
\text { 34. Independent (self-reliant, self-sufficient) } \\
\text { 35. Wisdom (a mature understanding of life) } \\
\text { 36. Loving (affectionate and tender) }\end{array}$ & \\
\hline $\begin{array}{l}\text { Knowledge of } \\
\text { Fair-Trade }\end{array}$ & $\begin{array}{l}\text { 1. The workers who produce Fair-trade products have } \\
\text { been treated with respect } \\
\text { 2. The workers who produce Fair-trade products have } \\
\text { been fairly paid } \\
\text { 3. Fair-trade products help alleviate poverty } \\
\text { 4. Fair-trade products help create a better world } \\
\text { 5. Fair-trade products are produced in safe, clean, } \\
\text { environments } \\
\text { 6. Environmentally sustainable practices are followed } \\
\text { during the production of Fair-trade products } \\
\text { 7. Fair-trade focuses on empowering women }\end{array}$ & $\begin{array}{l}\text { De Pelsmacker et al., } \\
\text { 2003; De Pelsmacker et } \\
\text { al., 2005; d'Astous, Alain, } \\
\& \text { Mathieu } 2008\end{array}$ \\
\hline $\begin{array}{c}\text { General } \\
\text { Attitudes } \\
\text { Towards Fair- } \\
\text { Trade }\end{array}$ & $\begin{array}{l}\text { 1. Fair-trade is too much like charity } \\
\text { 2. Purchasing Fair-trade does not solve anything in the } \\
\text { long run. It just eases your conscience } \\
\text { 3. Fair-trade lacks credibility } \\
\text { 4. Fair-trade makes me think of a colonial attitude by } \\
\text { means of which we impose our norms to others } \\
\text { 5. The Fair-trade principle cannot work on a larger scale } \\
\text { 6. Fair-trade is not compatible with free-market } \\
\text { principles: it is impossible to trade fairly and be } \\
\text { profitable } \\
\text { 7. Fair-trade is important } \\
\text { 8. Fair-trade ought to be a generalized way of trading } \\
\text { (the benchmark) and not an alternative way (the } \\
\text { exception) } \\
\text { 9. I am concerned about the Fair-trade issue }\end{array}$ & $\begin{array}{l}\text { De Pelsmacker and } \\
\text { Janssens, } 2005\end{array}$ \\
\hline $\begin{array}{l}\text { Attitudes } \\
\text { Towards } \\
\text { Purchasing } \\
\text { Fair-Trade } \\
\text { Coffee. }\end{array}$ & $\begin{array}{l}\text { 1. Fair-trade coffee is healthier } \\
\text { 2. Fair-trade coffee is tastier } \\
\text { 3. Fair-trade coffee is of better quality } \\
\text { 4. Fair-trade coffee should not be more expensive } \\
\text { 5. People buying Fair-trade coffee should be rewarded } \\
\text { for their good behaviors by not paying extra } \\
\text { 6. The purchase of free-trade coffee requires an } \\
\text { additional effort compared to regular coffee }\end{array}$ & $\begin{array}{l}\text { De Pelsmacker and } \\
\text { Janssens, } 2005\end{array}$ \\
\hline
\end{tabular}




\begin{tabular}{|c|c|c|}
\hline & 7. Fair-trade coffee should be less expensive & \\
\hline Subjective & 1. My friends think I should purchase Fair-trade coffee & Ajzen, I. (2001). \\
\hline \multirow[t]{3}{*}{ Norm } & 2. My family thinks I should purchase Fair-trade coffee & \\
\hline & $\begin{array}{l}\text { 3. My colleagues think I should purchase Fair-trade } \\
\text { coffee }\end{array}$ & \\
\hline & $\begin{array}{l}\text { 4. My classmates think I should purchase Fair-trade } \\
\text { coffee }\end{array}$ & \\
\hline \multirow[t]{3}{*}{ Intention } & $\begin{array}{l}\text { 1. I intend to purchase Fair-trade coffee within the next } \\
\text { month }\end{array}$ & Ajzen, I. (2001). \\
\hline & $\begin{array}{l}\text { 2. I plan to purchase Fair-trade coffee within the next } \\
\text { month }\end{array}$ & \\
\hline & $\begin{array}{l}\text { 3. I will purchase Fair-trade coffee within the next } \\
\text { month }\end{array}$ & \\
\hline
\end{tabular}

\section{Data collection}

Two sessions of data collection took place during this research project, the first was in November 2018 and the second was from January 2019 to April 2019. The survey was done in conjunction with the Ted Rogers School of Management (TRSM) Research Participation Sign-up System. This offered Ryerson University students an incentive of $0.25 \%$ credit towards select courses in exchange for their participation in my study. Consent was sought from participants by reading the modified script approved from Ryerson Ethics Board (Appendix A) which outlined a brief description, potential risks, and the contact information of myself and project supervisor. Participants had to press "Yes, continue" to proceed to the questionnaire or "No, exit" to be removed from the survey.

The first session of data collection was administered through an online portal were respondents simply had to answer an online questionnaire in order to fulfill requirements. The second data collection session, participants had to sign-up through an online portal during timeslots to screen a VR compatible video in a location within TRSM. The second group had to answer the first 36 questions measuring personal values before administering the VR video, followed by the remaining questions. 
A total of 314 responses were recorded between both sessions, which after excluding individuals who skipped and/or missed a question or answered groupings of questions all under the same response, 296 were deemed valid for analysis. 153 respondents from session 1 and 143 respondents from session 2 . The outlined sample population was administered through time, cost and accessibility constraints.

\section{Design and Procedures}

Participants were informed about the study through the university-run SONA research pool website. In exchange for partial course credit, participants were asked to complete an online survey (group 1). Group 2 signed up for timeslots where they watched a VR compatible video through their smartphone on an adaptable headset followed by a survey. There were no restrictions on general criteria (age, gender, income, education) other than the assumption that individuals who are participating are current Ryerson University students.

In the VR condition, participants were asked to watch a VR compatible video on their smartphones, which was amplified using a "Noon VR Plus Headset" (Appendix D) to create VR style 360-degree immersion. The Noon headsets in conjunction with the video's motion tracking system, allowed users to look around as they were present in the setting. For this study, I chose the video titled "Samuel's Fair-trade Journey" which was streamed using Youtube's VR compatible technology. The video presented was 4.40 minutes in length and was produced by The Fair-trade Foundation (2018). The video outlined the journey of a Fair-trade farmer's day to day life, what aspects go into making Fair-trade coffee, and the impact of Fair-trade. The Fairtrade Foundation is defined as "The international Fair-trade system (which the Fair-trade Foundation is a part of) represents the world's largest and most recognized Fair-trade system. We 
are a global organization working to secure a better deal for farmers and workers" (The Fairtrade Foundation, 2019). The primary objective of this video was to create awareness and knowledge on what Fair-trade is and how this affects people who produce these items. 


\section{Chapter 6. Results}

\section{Descriptive Statistics}

An analysis of the overall demographic statistics (Figure 7) was performed using the descriptive statistics feature on IBM SPSS Statistics 25 software. The first group had a considerably large number of female respondents compared to the second group which was more evenly distributed among genders. With respect to age, both groups saw the majority of its respondents fall under the 18-24 category with group 2 having an increase in older respondents. Statistics Canada determines that the median age of university students is 22.8 years of age and 24.8 upon graduation (Statistics Canada, 2010). Furthermore, my research has identified Generation Z (18-24) as a primary adopter and supporter of sustainable consumption (Nielsen, 2016). In terms of education, group 2 saw a large influx in "Bachelor's degree" which illustrates that students had previously completed a bachelor's program correlating with the older age demographic. Furthermore, higher levels of Full-time employment and lower levels of part-time employment were observed in group 2 respondents. Finally, both groups saw the bulk of its respondents fall under the "less than $\$ 20,000$ " and " $\$ 21,000$ to $\$ 40,000$ " category for household income. Statistics Canada outlines the average income for individuals aged $16-24$ as $\$ 16,100$ and $\$ 44,200$ for individuals aged 25-34 years of age (Statistics Canada, 2017). Overall, the recruitment process affected these numbers slightly as the two sessions of data collection were done in two different semesters. Therefore, this affected the range of classes offering extra credit-granting through SONA and the minor differences between sample groups. 
Table 4: Descriptive Statistics

\begin{tabular}{lcccc}
\hline & Group 1 & & Group 2 & \\
\hline & Frequency & $\begin{array}{c}\text { Percentage } \\
\text { (\%) }\end{array}$ & Frequency & Percentage (\%) \\
\hline Male & 47 & 30.5 & 70 & 49 \\
Female & 104 & 67.5 & 71 & 49.7 \\
Other & 2 & 2 & 2 & 1.4 \\
\hline $18-24$ & 150 & 97.4 & 116 & 81.1 \\
$25-34$ & 3 & 2.6 & 26 & 18.2 \\
$35-44$ & -- & -- & 1 & 0.7 \\
\hline High school diploma or... & 68 & 44.2 & 27 & 18.9 \\
Some postsecondary... & 72 & 46.8 & 54 & 37.8 \\
Bachelor's degree & 13 & 9 & 59 & 41.3 \\
Master's degree & -- & -- & 3 & 2.1 \\
\hline Full-time employment & 5 & 3.2 & 32 & 22.4 \\
Part-time employment & 111 & 72.2 & 76 & 53.1 \\
Unemployed & 37 & 24.6 & 35 & 24.5 \\
\hline Less Than $\$ 20,000$ & 45 & 29.2 & 49 & 34.3 \\
\$21,000 to $\$ 40,000$ & 33 & 21.4 & 36 & 25.2 \\
\$41,000 to $\$ 60,000$ & 24 & 15.6 & 19 & 13.3 \\
\$61,000 to $\$ 80,000$ & 8 & 5.2 & 17 & 11.9 \\
\$81,000 to $\$ 100,000$ & 14 & 9.2 & 11 & 7.7 \\
Above $\$ 100,000$ & 29 & 19.4 & 11 & 7.7 \\
\hline
\end{tabular}

\section{Factor Analysis \& Reliability Test}

Factor analysis is used to examine the convergent and discriminant validity. Convergent validity is the degree to which indicators of a precise construct converge or share a high variance in common (Hair et al., 2010). Discriminant validity is the degree to which construct is truly distinct from one another both in terms of how much it correlates with other constructs and how distinctly measured items measure a single item (Hair et al., 2010). In my research, exploratory factor analysis was used to identify the dimensionality of research variables using IBM SPSS Statistics 25 software.

Both group 1 and 2 were pooled in order to conduct factor analysis. Factor loading shows the correlation between each item and the related constructs. (Hair et al., 2010). According to Hair et al. (2010) 100 or more observations/respondents means a factor loading of 0.55 and 
higher is significant with a difference of 0.20 between loadings. Therefore, constructs which have factor loadings less than 0.55 or difference smaller than 0.20 between loadings were suppressed.

Principal component analysis with Varimax rotation was used for variables: Personal Values, Knowledge of Fair-trade, General Attitudes towards Fair-trade, Attitudes towards purchasing Fair-trade coffee, Subjective Norm, and Intention. Personal values generated two dimensions: Competence and Idealism, which was reduced from four in the theoretical model because they did not meet the outlined loading terms. Competence measures the personal beliefs which includes independent, clean, forgiving, and social recognition (De Pelsmacker et al., 2005). While Idealism represents a world at peace, courageous, national security, and intellectual (De Pelsmacker et al., 2005). General Attitude towards Fair-trade generated two dimensions: Skepticism and Concern. Skepticism measures the disbelief of respondents concerning the concept of Fair-trade. (De Pelsmacker et al., 2005). Comparatively, concern measures concern about the Fair-trade issue in general (De Pelsmacker et al., 2005). Finally, Attitudes towards purchasing Fair-trade coffee generated two dimensions: Product interest and likeability and Price Acceptability. Product interest and Likeability measures the idea that respondents were interested in Fair-trade products as well as the belief that Fair-trade products are healthier, tastier and of better quality than "normal" products (De Pelsmacker et al., 2005). Price acceptability measures the respondents' level of acceptance or disagreement to Fair-trade coffee prices (De Pelsmacker et al., 2005). All other variables loaded under one component where knowledge of Fair-trade measures the competence in accurately defining Fairtrade (De Pelsmacker et al., 2005). Subjective norms measure the individual's perception or opinion about what others believe the individual should do. Lastly, purchase intention which measures behavioral purchase intention of 
Fair-trade coffee. The internal consistency of multiple indicators was examined using Cronbach

Alpha where $\alpha=.70$ or higher was deemed significant (Hair et al., 2010).

Table 5: Correlation loading and Cronbach Alpha measurement of reliability

\begin{tabular}{|c|c|c|}
\hline Dimension & $\begin{array}{l}\text { Factor } \\
\text { Loading }\end{array}$ & $\begin{array}{l}\text { Cronbach } \\
\text { Alpha }\end{array}$ \\
\hline $\begin{array}{l}\text { Personal Values / Rokeach Value Scale: Competence } \\
\text { Q1-30 Social Recognition } \\
\text { Q1-31 Clean } \\
\text { Q1-32 Forgiving } \\
\text { Q1-34 Independent }\end{array}$ & $\begin{array}{l}.775 \\
.713 \\
.802 \\
.721\end{array}$ & .790 \\
\hline $\begin{array}{l}\text { Personal Values / Rokeach Value Scale: Idealism } \\
\text { Q1-1 A world at Peace } \\
\text { Q1-2 Intellectual } \\
\text { Q1-3 Courageous } \\
\text { Q1-16 National Security }\end{array}$ & $\begin{array}{l}.801 \\
.742 \\
.778 \\
.803\end{array}$ & .830 \\
\hline $\begin{array}{l}\text { Knowledge of Fair-trade } \\
\text { Q2-1 The workers who produce Fair-trade products have been treated with respect } \\
\text { Q2-2 The workers who produce Fair-trade products have been fairly paid } \\
\text { Q2-3 Fair-trade products help alleviate poverty } \\
\text { Q2-4 Fair-trade products help create a better world } \\
\text { Q2-5 Fair-trade products are produced in safe, clean, environments } \\
\text { Q2-6 Environmentally sustainable practices are followed during the production of Fair-trade products } \\
\text { Q2-7 Fair-trade focuses on empowering women }\end{array}$ & $\begin{array}{l}.759 \\
.786 \\
.809 \\
.692 \\
.846 \\
.773 \\
.681\end{array}$ & .879 \\
\hline $\begin{array}{l}\text { General Attitude towards Fair-trade: Skepticism } \\
\text { Q3-1 Fair-trade is too much like charity } \\
\text { Q3-2 Purchasing Fair-trade does not solve anything in the long run. It just eases your conscience } \\
\text { Q3-3 Fair-trade lacks credibility } \\
\text { Q3-4 Fair-trade makes me think of a colonial attitude by means of which we impose our norms to others } \\
\text { Q3-5 The Fair-trade principle cannot work on a larger scale } \\
\text { Q3-6 Fair-trade is not compatible with free-market principles: it is impossible to trade fairly and be profitable }\end{array}$ & $\begin{array}{l}.821 \\
.854 \\
.768 \\
.798 \\
.860 \\
.821\end{array}$ & .904 \\
\hline $\begin{array}{l}\text { General Attitude towards Fair-trade: Concern } \\
\text { Q3-7 Fair-trade is important } \\
\text { Q3-8 Fair-trade ought to be a generalized way of trading (the benchmark) and not an alternative way (the exception) } \\
\text { Q3-9 I am concerned about the Fair-trade issue }\end{array}$ & $\begin{array}{l}.806 \\
.781 \\
.671 \\
\end{array}$ & .717 \\
\hline $\begin{array}{l}\text { Attitudes towards purchasing Fair-trade coffee: Product interest and } \\
\text { likeability } \\
\text { Q5-1 Fair-trade coffee is healthier } \\
\text { Q5-2 Fair-trade coffee is tastier } \\
\text { Q5-3 Fair-trade coffee is of better quality }\end{array}$ & $\begin{array}{l}.868 \\
.898 \\
.853\end{array}$ & .862 \\
\hline $\begin{array}{l}\text { Attitudes towards purchasing Fair-trade coffee: Price Acceptability } \\
\text { Q5-4 Fair-trade coffee should not be more expensive } \\
\text { Q5-5 People buying Fair-trade coffee should be rewarded for their good behaviors by not paying extra } \\
\text { Q5-7 Fair-trade coffee should be less expensive }\end{array}$ & $\begin{array}{l}.848 \\
.837 \\
.929\end{array}$ & .859 \\
\hline Subjective Norms & & .939 \\
\hline
\end{tabular}




\begin{tabular}{l|l|l}
\hline Q6-1 My friends think I should purchase Fair-trade coffee & .945 & \\
Q6-2 My family thinks I should purchase Fair-trade coffee & .870 & \\
Q6-3 My colleagues think I should purchase Fair-trade coffee & .941 & \\
Q6-4 My classmates think I should purchase Fair-trade coffee & .922 & \\
\hline Intention & & .965 \\
Q8-1 I intend to purchase Fair-trade coffee within the next month & .962 & \\
Q8-2 I plan to purchase Fair-trade coffee within the next month & .981 & \\
Q8-3 I will purchase Fair-trade coffee within the next month & .958 & \\
\hline
\end{tabular}

Revised Model and Hypotheses

The factor analysis loaded fewer dimensions for personals values when considering our proposed conceptual, therefore, I present the revised model and hypotheses:

Figure 4: Revised Model

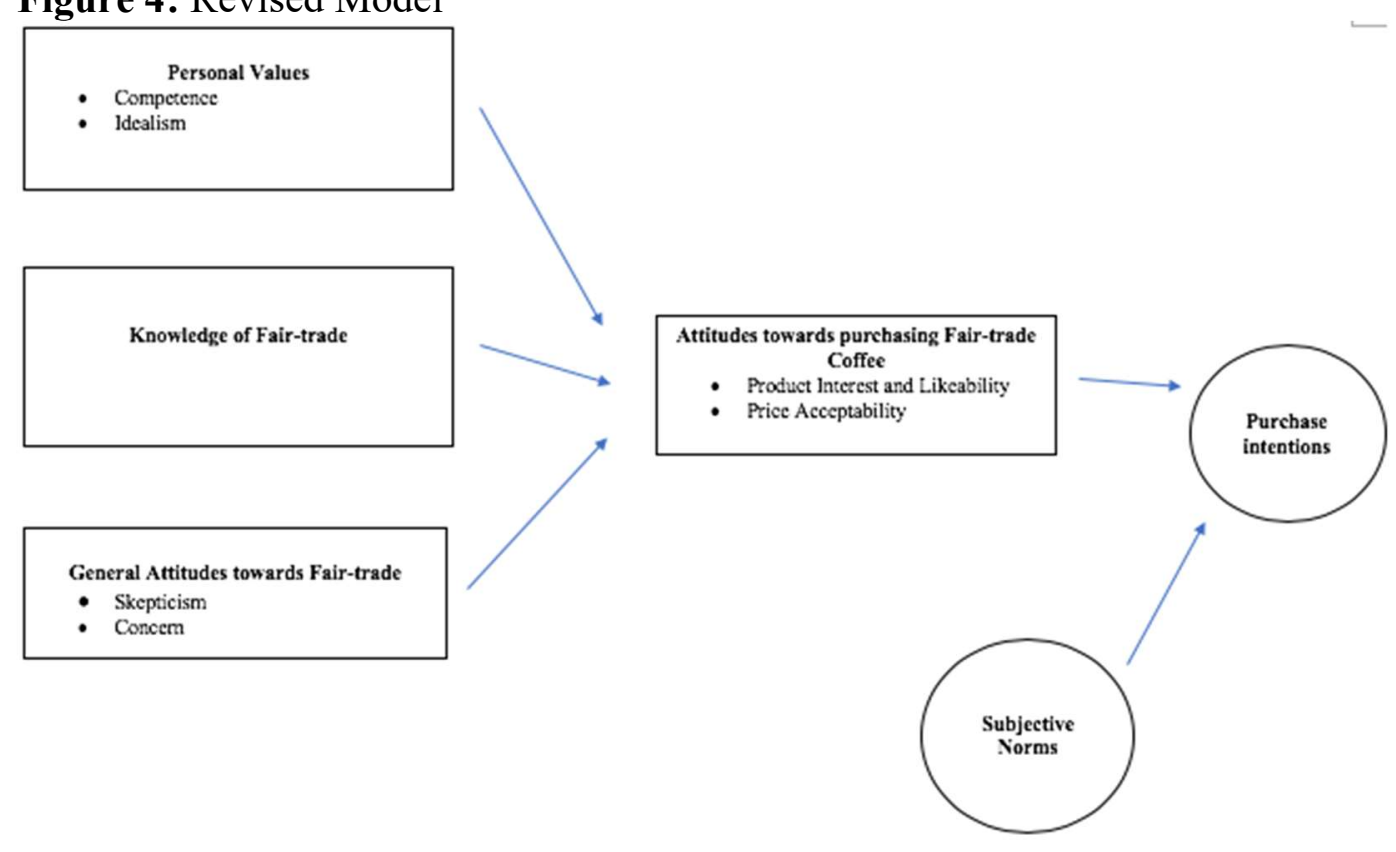

Table 6: Revised summary of hypotheses

\section{Hypotheses}

H1a: Product Interest and Likeability will be a significant predictor of purchase intention

H1b: Price Acceptability will be a significant predictor of purchase intention

H2: Subjective Norms will be a significant predictor of purchase intention.

H3a: Competence will be a significant predictor of Product Interest and Likeability

H3b: Competence will be a significant predictor of Price Acceptability

H4a: Idealism will be a significant predictor of Product Interest and Likeability

H4b: Idealism will be a significant predictor of Price Acceptability

H5a: Knowledge of Fair-trade will be a significant predictor of Product Interest and

Likeability 
H5b: Knowledge of Fair-trade will be a significant predictor of Price Acceptability

H6a: Skepticism will be a significant predictor of Product Interest and Likeability

H6b: Skepticism will be a significant predictor of Price Acceptability

H7a: Concern will be a significant predictor of Product Interest and Likeability

H7b: Concern will be a significant predictor of Price Acceptability

\section{Study 1}

Multiple Regression

Study 1 was used to test the conceptual model where a multiple regression analysis was performed on IBM SPSS Statistics 25 software. Multiple regression is used to predict the value of a variable based on the value of two or more other variables (Laerd Statistic, 2019). The variable to predict can be called dependent variable, the outcome variable, target or even criterion variable. The variables used to predict are called independent variables or predictor variables. Multiple regression allows us to determine the fit or variance explained of a presented model. These insights help conclude the relative contribution of each predictor to the total variance explained (Laerd Statistic, 2019).

Personal Values, Knowledge about Fair-trade, General attitude towards Fair-trade -> Product Interest and Likeability)

The overall regression model was significant $\mathrm{F}(5,147)=11.963, \mathrm{P}<0.001, \mathrm{R}^{2}=0.289$. Where Competence, Idealism, Knowledge, Skepticism and Concern account for $29 \%$ of the variance in Product Interest and Likeability. Competence P-value $=0.004<0.01$, Knowledge Pvalue $=0.00<0.001$, Skepticism P-value $0.047<0.05$, and Concern $\mathrm{P}$-value $=0.037<0.05$ are all significant predicators of Product Interest and Likeability. 
Table 7: Product Interest and Likeability Regression

\begin{tabular}{|lllll|}
\hline & Stand. Coef. Beta & Std. Err. & (t-value) & (P-value) \\
\hline Competence & .257 & 2.803 & 2.935 & $.004^{* *}$ \\
Idealism & -.104 & 2.939 & -1.192 & .235 \\
Knowledge & .358 & 2.068 & 4.758 & $.000^{* * *}$ \\
Skepticism & .142 & 1.866 & 2.001 & $.047^{*}$ \\
Concern & .172 & 2.528 & 2.106 & $.037^{*}$ \\
\hline
\end{tabular}

***Significant at $\mathrm{p}<.001,{ }^{* *}$ Significant at $\mathrm{p}<.01,{ }^{*}$ Significant at $\mathrm{p}<.05$

Personal Values, Knowledge about Fair-trade, General attitude towards Fair-trade-> Price Acceptability

The overall regression model was significant $F(5,147)=5.089, \mathrm{P}<0.001, \mathrm{R}^{2}=0.148$.

Where Competence, Idealism, Knowledge, Skepticism and Concern account for $15 \%$ of the variance in Price Acceptability. Knowledge P-value $=0.004<0.05$ and Skepticism Pvalue $=0.001<0.001$ are significant predictors of Price Acceptability.

Table 8: Price Acceptability Regression

\begin{tabular}{|lllll|}
\hline & Stand. Coef. Beta & Std. Err. & (t-value) & (P-value) \\
\hline Competence & .038 & 3.380 & .397 & .692 \\
Idealism & -.125 & 3.544 & -1.301 & .195 \\
Knowledge & .238 & 2.494 & 2.890 & $.004^{* *}$ \\
Skepticism & .259 & 2.250 & 3.338 & $.001^{* *}$ \\
Concern & .126 & 3.048 & 1.408 & .161 \\
\hline
\end{tabular}

${ }^{* * *}$ Significant at $\mathrm{p}<.001,{ }^{*}$ Significant at $\mathrm{p}<.01,{ }^{*}$ Significant at $\mathrm{p}<.05$

Attitudes towards purchasing Fair-trade coffee, Subjective norms-> Purchase intention

The overall regression model was significant $\mathrm{F}(3.149)=12.992, \mathrm{P}<0.001, \mathrm{R}^{2}=0.207$.

Where Product Interest and Likeability, Price Acceptability and Subjective Norm account for $21 \%$ percent of the variance in purchase intention. Subjective Norm is seen as the only significant predictor of intention where $\mathrm{P}$-value $=0.00<0.001$. 
Table 9: Purchase Intention Regression

\begin{tabular}{|lllll|}
\hline & Stand Coef. Beta & Std. Err. & (t-value) & (P-value) \\
\hline Product Interest and Likeability & .134 & .004 & 1.716 & .088 \\
Price Acceptability & -.038 & .004 & -.465 & .643 \\
Subjective Norms & .418 & .004 & 5.282 & $.000^{* * *}$ \\
\hline
\end{tabular}

***Significant at $\mathrm{p}<.001,{ }^{* *}$ Significant at $\mathrm{p}<.01,{ }^{*}$ Significant at $\mathrm{p}<.05$

Figure 5: Study 1 model with significant paths

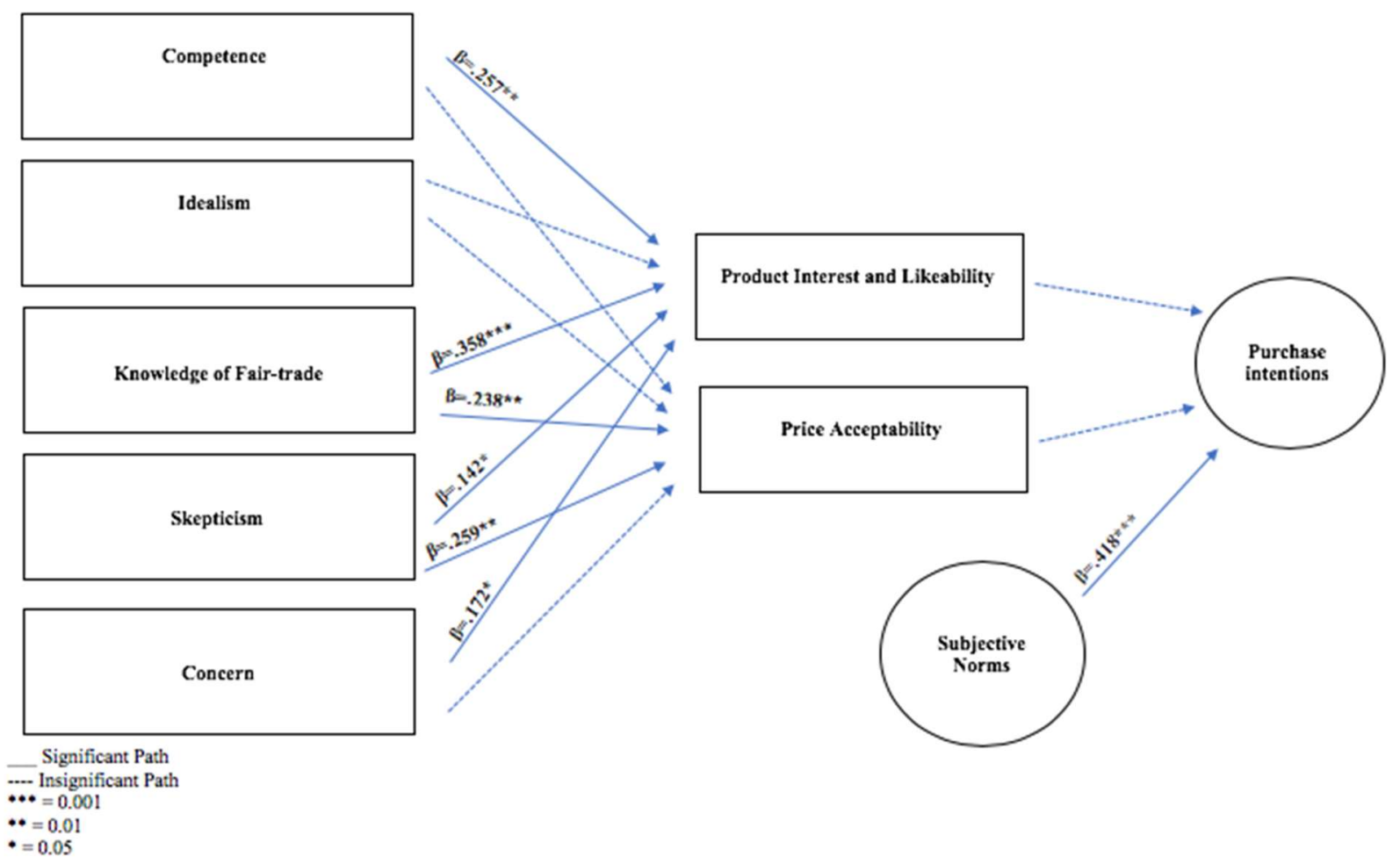

Discussion

Firstly, Study 1 demonstrated that competence was a significant predictor of product interest and likeability. Anderson and Cumming (1972) found that personal competence was directly related to ethical consumer behaviour which was confirmed as we accepted $H 3 a$. That said, competence was not a significant predictor of price acceptability and idealism was not a significant predictor of product interest and likeability or price acceptability. Therefore, $H 3 b$, $H 4 a$, and $H 4 b$ were rejected. Although literature by De Pelsmacker al., (2005) suggested that 
idealism and hedonic predisposition were personal values determinant to Fair-trade buying behaviour this was not the case. In this case, the population sample and age range did not equal the vastness of the suggested literature's national survey. Other research suggests Schwartz Value Theory was a successful measure of personal values in term of Fair-trade consumers (Doran 2009, 2010, Shaw et al., 2005). Furthermore, The literature on organic and Fair-trade values suggests that organic attitudes/values are mostly associated idealism whereas social and political attitudes/values are related to purchasing Fair-trade product (Dickson, 2000). Organic values were outlined as being idealistic, taking responsibility for the actions of others, and sympathetic to the idea that the notion can work (Dickson, 2000). Fair-trade values were outlined as courageous, broad-minded, and free to choose (Dickson, 2000). Therefore, suggesting that the values in my research may have aligned stronger with organic versus Fair-trade values.

Knowledge of Fair-trade was found to be a significant predictor of product interest and likeability and price acceptability. DePelsmacker, Patrick, \& Janssens (2007) found that more people have knowledge about the issue of Fair-trade, led to an increase in attitudes towards purchasing Fair-trade which was confirmed as we accepted $H 5 a$ and $H 5 b$. Skepticism (General Attitudes towards Fair-trade) was found to be a significant predictor of product interest and likeability and price acceptability and concern (General Attitudes towards Fair-trade) was a significant predictor of product interest and likeability. Skepticism resulted in a positive beta value which literature outlined as a negative view. This can be attributed to respondents being so skeptical of Fair-trade that this may have increased their curiosity and in turn their interest and likeability of the product as well as their price acceptability. Confusion, lack of credibility, and erosion of customer confidence (Salzhauer, 1991; Teisl, Roe and Levy, 1999; Nilsson, Tunçer and Thidell, 2004) were all attitudes presented by literature regarding labelling certifications and 
organizations tied to Fair-trade which was confirmed as we accepted $H 6 a, H 6 b$, and $H 7 a$.

Comparatively, concern (General Attitudes towards Fair-trade) was not a significant predictor of price acceptability. Nielsen's 2016 poll in over 60 countries saw $66 \%$ percent of global consumers willing to pay more for sustainable goods versus a whopping 73 percent of Gen $\mathrm{Z}$ willing to do the same (Nielsen, 2016). The primary makeup of my sample was generation $\mathrm{Z}$ which literature outlined an increase in this age groups willingness to pay for Fair-trade product. Therefore, we reject $H 7 b$.

Subjective norms were found to be a significant predictor of purchase intentions. Literature from Ozcaglar-Toulouse et al. (2006) suggested subjective norms explained significantly purchase intentions of "never" or "rarely' Fair-trade shoppers. Additionally, research by Oberseder et al. (2011) suggested that an important variable to integrate within corporate social responsibility (CSR) consumer behaviour is peer influence. Product interest and likeability and price acceptability (Attitudes towards purchasing Fair-trade coffee) were not significant predictors of purchase intentions. Research presented from Nicholls and Lee (2006) suggested consumers' knowledge, awareness, and favourable attitudes concerning Fair-trade products and ethical concerns did not necessarily lead to purchase intentions among younger sample group. Additionally, research from Ma et al, (2012) suggests that "findings from previous Fair-trade studies that were based on other generational cohorts may not be applicable to the young consumer groups who have some distinctive consumption behaviours" (Ma et al, 2012, p.46). Therefore, rejecting H1a and H1b.

Table 10: Summary Hypotheses Results Study 1

\begin{tabular}{l|l}
\hline Hypotheses & Reject or Accept \\
\hline $\begin{array}{l}\text { H1a: Product Interest and Likeability will be a } \\
\text { significant predictor of purchase intention }\end{array}$ & Reject \\
\end{tabular}




\begin{tabular}{l|l}
\hline $\begin{array}{l}\text { H1b: Price Acceptability will be a significant } \\
\text { predictor of purchase intention }\end{array}$ & Reject \\
\hline $\begin{array}{l}\text { H2: Subjective Norms will be a significant } \\
\text { predictor of purchase intention. }\end{array}$ & Accept \\
\hline $\begin{array}{l}\text { H3a: } \text { Competence will be a significant } \\
\text { predictor of Product Interest and Likeability }\end{array}$ & Accept \\
\hline $\begin{array}{l}\text { H3b: } \text { Competence will be a significant } \\
\text { predictor of Price Acceptability }\end{array}$ & Reject \\
\hline $\begin{array}{l}\text { H4a: Idealism will be a significant predictor of } \\
\text { Product Interest and Likeability }\end{array}$ & Reject \\
\hline $\begin{array}{l}\text { H4b: Idealism will be a significant predictor of } \\
\text { Price Acceptability }\end{array}$ & Reject \\
\hline $\begin{array}{l}\text { H5a: } \text { Knowledge of Fair-trade will be a } \\
\text { significant predictor of Product Interest and } \\
\text { Likeability }\end{array}$ & Accept \\
\hline $\begin{array}{l}\text { H5b: Knowledge of Fair-trade will be a } \\
\text { significant predictor of Price Acceptability }\end{array}$ & Accept \\
\hline $\begin{array}{l}\text { H6a: Skepticism will be a significant predictor } \\
\text { of Product Interest and Likeability }\end{array}$ & Accept \\
\hline $\begin{array}{l}\text { H6b: Skepticism will be a significant predictor } \\
\text { of Price Acceptability }\end{array}$ & Accept \\
\hline $\begin{array}{l}\text { H7a: } \text { Concern will be a significant predictor of } \\
\text { Product Interest and Likeability }\end{array}$ & Accept \\
\hline $\begin{array}{l}\text { H7b: } \text { Concern will be a significant predictor of } \\
\text { Price Acceptability }\end{array}$ & Reject \\
\end{tabular}

Study 2

T-test

Study 2 was used to seek answers to the research question regarding the VR's effect on variables in the conceptual model. A series of T-test analyses was performed using IBM SPSS Statistics 25 software. A T-Test is used to infer whether there is a significant difference between the means of two groups (Kenton, 2019). Furthermore, it can be used as a tool to test hypotheses and assumptions before using additional statistical methods. I used the independent sample t-test on the TRA constructs; Knowledge of Fair-trade, General attitudes towards Fair-trade (Skepticism and Concern), Attitudes towards purchasing Fair-trade coffee (product interest and likeability and price acceptability), Subjective Norms, and Purchase Intention to explore 
preliminary differences on whether VR may have an effect on mean differences. We excluded personal belief/values as these are innate characters that describe our self-makeup and should not be impacted by environmental settings.

Figure 17 displays Knowledge as significant because $\mathrm{P}=.000<0.001$ and observed a higher mean score from 4.86 in group 1 to 5.29 in group 2. Skepticism was not significant because $\mathrm{P}=0.851>0.05$ but noticeably observed a higher mean score from 3.43 in group 1 to 3.46. Concern was significant because $\mathrm{P}=0.005<0.01$ and observed a higher mean score from 4.93 in group 1 to 5.26 in group 2. Product interest and likeability was significant because $\mathrm{P}=0.023<0.05$ and observed a higher mean score from 4.52 in group 1 to 4.79 in group 2 . Figure 17 also indicates that Subjective Norms is significant because $\mathrm{P}=0.002<0.01$ and observed a higher mean score from 3.71 in group 1 to 4.20 in group 2. Finally, Intention is found as significant because $\mathrm{P}=0.00<0.001$ and observed a higher mean score from 3.69 in group 1 to 4.37 in group 2.

Table 11: T-test summary

\begin{tabular}{|c|c|c|c|c|c|c|}
\hline Construct & $\begin{array}{c}\text { Mean } \\
\text { Group } 2\end{array}$ & $\begin{array}{c}\text { Std. Dev. } \\
2\end{array}$ & $\begin{array}{c}\text { Mean } \\
\text { Group } 1\end{array}$ & $\begin{array}{l}\text { Std. } \\
\text { Dev. } 1\end{array}$ & T-value & $\begin{array}{c}P \text { - } \\
\text { value }\end{array}$ \\
\hline Knowledge & 5.29 & .97 & 4.86 & 1.12 & $3.56^{* * *}$ & .000 \\
\hline Skepticism & 3.46 & 1.39 & 3.43 & 1.17 & 188 & .851 \\
\hline Concern & 5.26 & .92 & 4.93 & .99 & $2.85 * *$ & .005 \\
\hline $\begin{array}{l}\text { Product Interest and } \\
\text { Likeability }\end{array}$ & 4.79 & 1.32 & 4.52 & 1.21 & $1.80^{*}$ & .023 \\
\hline Price Acceptability & 4.05 & 1.57 & 4.23 & 1.37 & 1.08 & 283 \\
\hline Subjective Norm & 4.20 & 1.35 & 3.71 & 1.32 & $3.17 * *$ & .002 \\
\hline Intention & 4.37 & 1.55 & 3.69 & 1.63 & $3.67 * * *$ & .000 \\
\hline
\end{tabular}




\section{Discussion}

Knowledge of Fair-trade

Figure 6: Box plot T-test results, Knowledge of Fair-trade

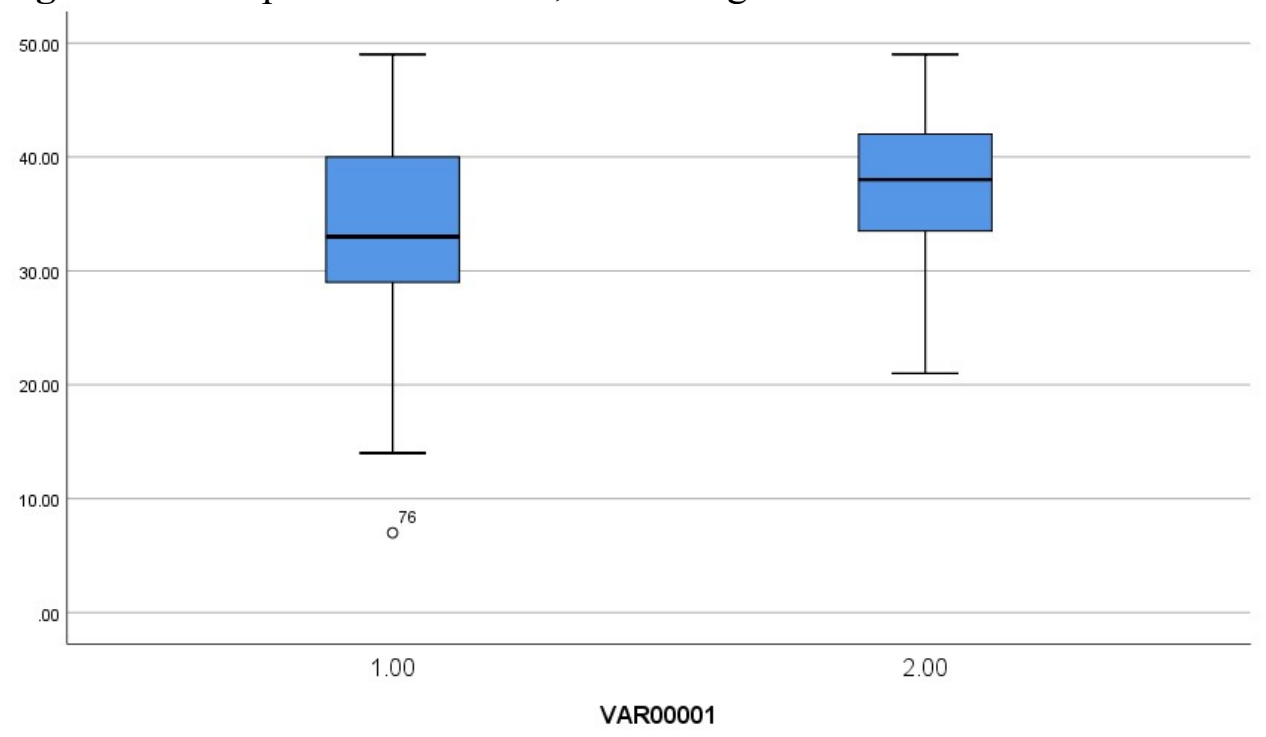

Knowledge of Fair-trade was significant $\mathrm{P}=.000<0.001$ and observed a higher mean score in group 2. Literature suggests that VR's presence, entertainment, and most important interactivity have all led to positive educational results (Jacobson \& Holden, 2005; Mikropoulos, 2006; Roussou, 2004; Roussou et al., 2006). Additionally, research from Youngblut (1998) suggests that VR's experientially engaging process immerses students into the educational process and leads to higher retention of new knowledge and mastery. In turn, contributing to the higher mean score observed in group 2. 
General attitudes towards Fair-trade

Figure 7: Box plot T-test results, Concern and Skepticism

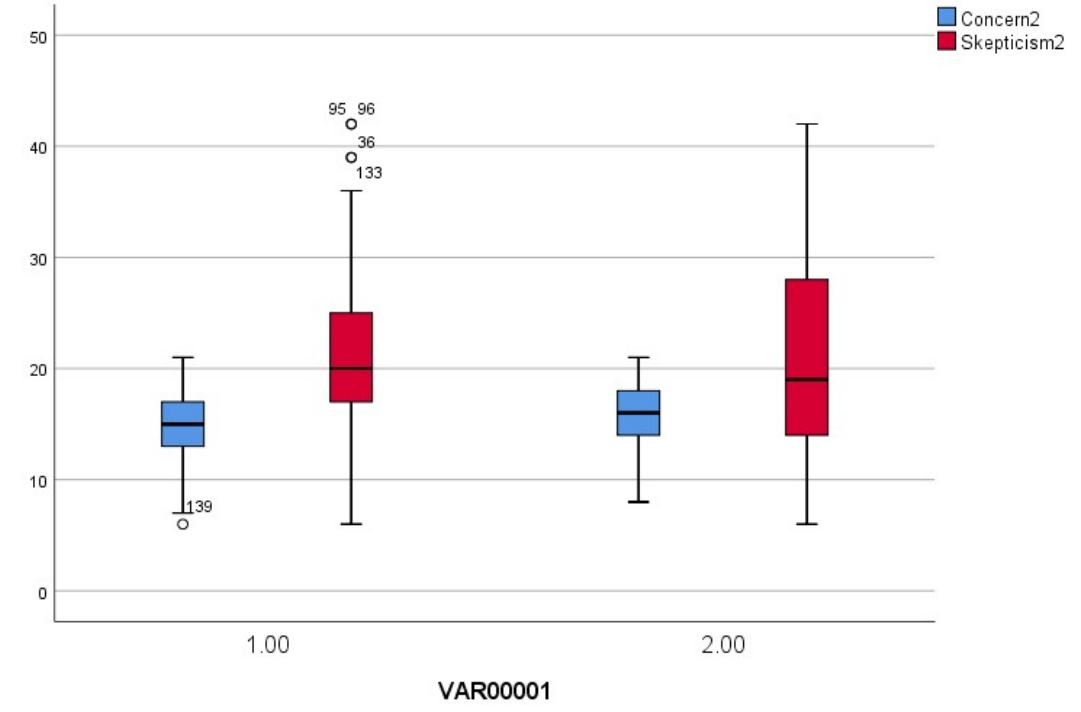

Concern was significant because $\mathrm{P}=0.005<0.01$ and observed a higher mean score of 5.26 for group 2. Skepticism, on the other hand, was not significant because $\mathrm{P}=0.851>0.05$ but noticeably observed a higher mean score of 3.46 for group 2. Research from Schuemie et al. (2001) suggests that the concept of presence explains the effectiveness of VR in shaping attitudinal and behavioral responses to virtual stimuli. Additionally, Suh and Lee (2005) concludes that VR experiences lead to positive attitudinal and behavioral outcomes, such as increasing consumer product knowledge. In turn, contributing to the higher mean score observed in group 2. Comparatively, VR provided a positive message regarding Fair-trade coffee farming and skepticism represented a negative feeling therefore the video didn't generate feelings skepticism and we found insignificant results. 
Attitudes towards purchasing Fair-trade Coffee

Figure 8: Box plot T-test results, Product interest and likeability and price acceptability

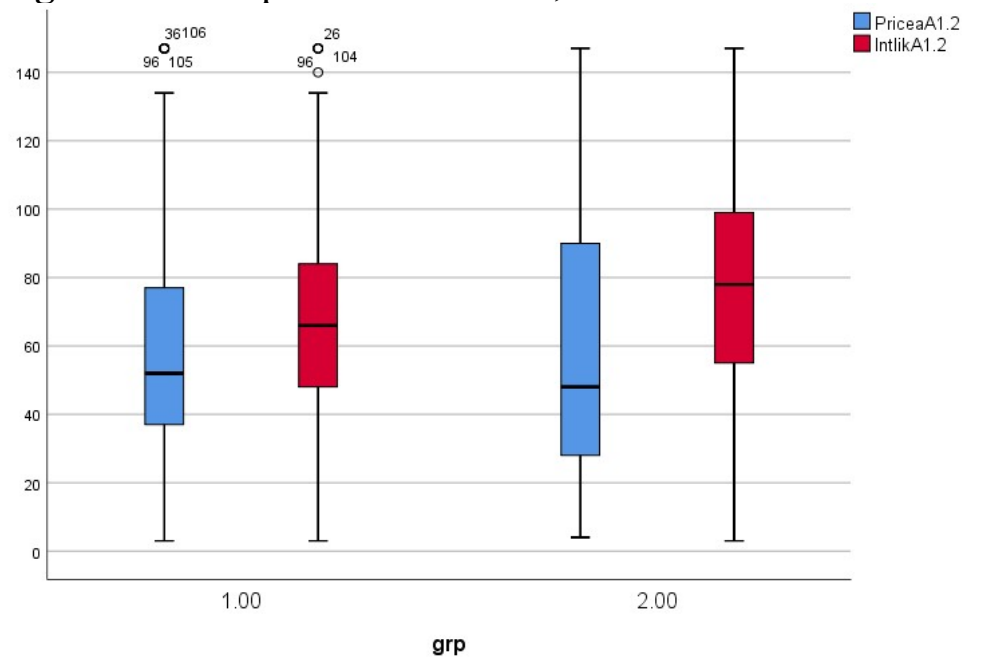

Product interest and likeability was deemed significant $\mathrm{P}=0.023<0.05$ and observed a higher mean score in group 2. Comparatively, price acceptability was insignificant because Pvalue $>.05$ and did not observe a higher mean score in group 2. Literature outlined VR's potential to create a more favourable brand attitude (Li et al. 2002; Suh and Lee 2005; Li et al. 2001; Suh and Chang 2006). Additionally, literature from Tussyadiah et al. (2018) concluded that VR's effect of presence and overall enjoyment positively impacted attitudes. In turn, contributing to the higher mean score observed in group 2. The initial excitement and newness of VR may have taken away from the absorption of information regarding the video therefore not effecting price acceptability resulting in insignificant results. 


\section{Subjective Norms}

Figure 9: Box plot T-test results, Subjective Norms

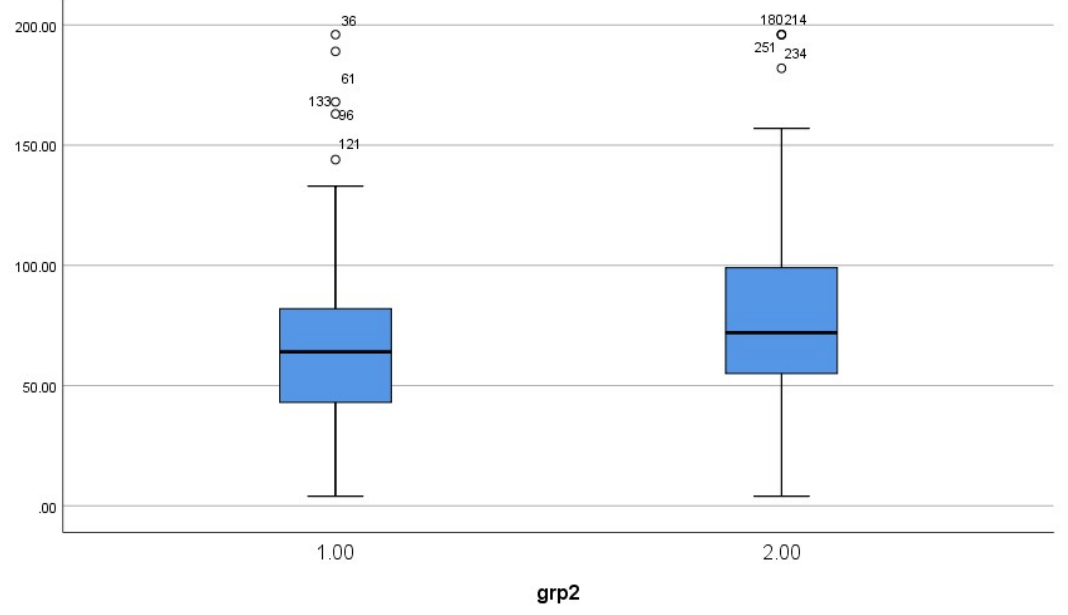

Subjective norms T-test was significant $\mathrm{P}=0.002<0.01$ and observed a higher mean score

of 4.20 for group 2. Literature outlined subjective norms as an important factor determining purchase intention in Fair-trade consumption (De Leeuw et al. 2014; Ozcaglar-Toulouse et al. 2006; Tarkiainen and Sundqvist 2005). Additionally, research from Shin (2008) suggests that subjective norms was a determining factor in purchase intentions regarding virtual economic environments. In turn, contributing to the higher mean score observed in group 2.

Purchase Intention

Figure 10: Box plot T-test results, Purchase intention

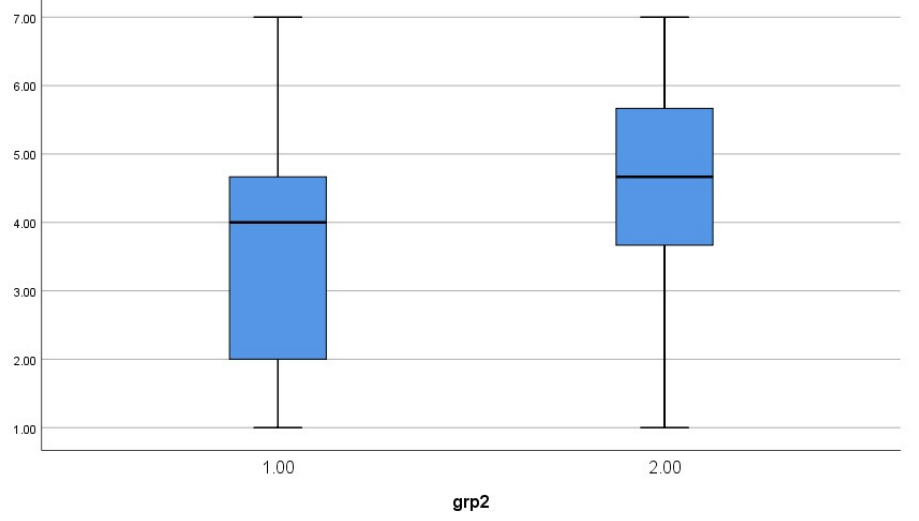


Purchase intention T-test was significant $\mathrm{P}=0.00<0.001$ and observed a higher mean score of 4.37 for group 2. Research from Li et al. (2001) suggested that 3-D advertising/marketing environments increased purchase intentions versus traditional 2-D environments. Additionally, research from Kim and Bioca (1997) suggests that presence in computer-meditated environments positively influence buying intention for products. In turn, contributing to the higher mean score observed in group 2.

In summary, the t-test observed higher mean scores for group 2 in all significant results. That said, there may be alternative explanations regarding the different mean scores observed in group 1 and group 2. For example, VR provided a positive message regarding Fair-trade coffee farming and skepticism represented a negative attitude towards Fair-trade in general. Therefore, the video didn't generate attitudes of skepticism and we found insignificant results. Additionally, the initial excitement and newness of VR may have taken away from the absorption of valuable information regarding the video. As a result, the effect of VR is inconclusive in the current study. 


\section{Chapter 7. Conclusion}

I began this research by investigating to what extent does Personal Values, Knowledge of Fair-trade, and General Attitudes Towards Fair-trade influence Attitudes towards Purchasing Fair-trade Coffee. Furthermore, to what extent does Attitudes towards Purchasing Fair-trade Coffee and Subjective Norms influence Purchase Intention. Lastly, how does VR impact these variables except for Personal Values? In this research competence, knowledge of Fair-trade, skepticism, and concern were found a significant predictors of product interest and likeability (Attitudes towards purchasing Fair-trade coffee). Additionally, knowledge of Fair-trade and Skepticism were significant predictors of price acceptability (Attitudes towards purchasing Fairtrade coffee). Finally, subjective norms were found as a significant predictor of purchase intention.

Idealism was not a significant predictor of product interest and likeability and price acceptability and competence not a significant predictor of price acceptability. Literature outlined organic attitudes/values are mostly associated with idealism whereas social and political attitudes/values are related to purchasing Fair-trade product (Dickson, 2000). Suggesting that FT consumers are predisposed toward equality and social justice values and this researched aligned more with organic values. Furthermore, literature suggested that alternative methods may be stronger in defining values for ethical/sustainable consumers. Concern was an insignificant predictor or price acceptability where the primary makeup of my sample was Gen Z. Literature outlined this generation as increasingly willing to adopt ethical/sustainable practices and willingness to pay. Finally, product interest and likeability and price acceptability were insignificant predictors of purchase intentions were literature suggested findings from previous 
Fair-trade studies that were based on other generational cohorts may not be applicable to the young consumer groups who have some distinctive consumption behaviours (Ma et al, 2012).

The t-test observed higher mean scores for group 2 in all significant results. VR was seen to educate, market, and create value with its media richness, presence, interactive, and immersive qualities. The exploratory analysis found skepticism and price acceptability as insignificant factors. VR provided a positive message regarding Fair-trade coffee farming and skepticism represented a negative attitude towards Fair-trade in general. Therefore, the video didn't generate attitudes of skepticism and we found insignificant results . Furthermore, the initial excitement and newness of VR may have taken away from the absorption of valuable information regarding price acceptability and generated insignificant results. That said, there may be alternative explanations regarding the different mean scores observed in group 1 and group 2. As a result, the effect of VR is inconclusive in the current study. As mentioned above, T-test is generally a tool to test hypotheses and assumptions before using additional statistical methods. That said, in order to draw future conclusions more research must be completed in order to further develop relationships between VR's potential in aiding Fair-trade coffee and its purchase intentions.

Lastly, this thesis has outlined the growing consumption of ethical/sustainable products and adoption VR technology from Gen Z. Literature has concluded that past research on ethical/sustainable consumption must be re-visited as Gen $\mathrm{Z}$ has distinctive consumption behaviour compared to other generational cohorts. In turn, the findings suggest that Gen Z outline the importance of subjective norms as a significant predictor of purchase intention and VR has a preliminary inconclusive effect on impacting dimensions within purchase intentions towards Fair-trade coffee. These results outline the future application of VR technology, the 
growing change in generational consumer behavior, and increasing relevance of ethical/sustainable consumption.

\section{Implications}

As presented, Fair-trade consumers have seen a large shift in demand and growth over the last few years. This thesis aims to expand the TRA theory and explore how the dimensions shift under the exploratory effect of VR in the context of Generation Z. Previous literature has outlined the importance of attitudes towards purchasing Fair-trade, the dimensions that influence these attitudes and subjective norms on purchase intentions. However, a growth in ethical consumption interest and adoption from Generation $\mathrm{Z}$ has created a market that could leverage technology such as VR to influence consumer behavior. Currently there is a multitude of information presenting VR's use in educational, marketing, and virtual environments such as gaming. A clear gap is presented where VR technology can be leveraged to market specialty products where value can be created leveraging its immersive qualities. There is need for research in this area to understand why the growth of consumption in Fair-trade products for Generation $\mathrm{Z}$ is increasing but is estimated at only 10 percent of worldwide market share and performs below standard in most countries outside of Europe (Fair-trade International, 2018). Unless the gaps and barriers are identified, the level of engagement and interest from consumers will remain stagnant and slow in growth.

This thesis identified generation $\mathrm{Z}$ as a group increasingly willing to adopt ethical/sustainable consumption. Additionally, the research outlined important factors such as knowledge about Fair-trade, skepticism, concern, product interest and likeability, and price acceptability as dimensions influencing their attitudes towards purchasing Fair-trade coffee. Although VR's results observed higher mean scores, further research must be conducted in order 
to grow inconclusive results. With the outlined scope of individuals and significant dimensions, new research must be presented in order to leverage consumer behavior, encourage Fair-trade consumption and in-turn ethical-sustainable consumption.

\section{Limitations}

As with all research, there are several limitations to this study. The first is concerned with the overarching representativeness or accuracy of the results. Dr. Norman Blaikie expert on social research discusses this, "the most serious threat to the possibility of generalizing results obtained in social experiments comes from the fact that people may behave differently in experimental situations than they do in natural situations (Blaikie, 2007, P.169). Although this is an important consideration to leverage the most authentic behaviour, in this circumstance, an artificial setting was necessary to keep environment conditions (VR) constant for all respondents.

Next, both studies where used leveraging Ryerson's student research pool. This was used for its accessibility, timeliness, and effective sample size. As this is an exploratory research into a new area of study, I believe the means of sampling is an adequate starting point. However, I acknowledge that having a better depth in age range would definitely give stronger results and considerations regarding VR's impact on Fair-trade purchase intentions. Furthermore, this younger generation is technology adopters therefore, having a wider spread age demographic might have made the VR technology more impactful in terms of its different dimensions. Thus, more research must be presented regarding a larger depth ages in order to increase external validity and draw conclusions on larger sample demographic.

Thirdly, participants were asked to answer numerous questions regarding Fair-trade products and Fair-trade coffee. Although a small definition in the questionnaire was provided, it is unfair to assume that all respondents are well educated in what makes a product Fair-trade. 
Furthermore, the research study focused specifically on VR's potential to educate and market Fair-trade coffee, but no specification was made in order to identify if respondent actually drank coffee. That said, research has proven that an indication to do something is directly linked to the action of doing it. People who indicate increased intention for action are more likely to perform action versus those who do not indicate intention (Liu \& Aaker, 2008).

Additionally, the study used very basic and inexpensive VR technology in combination with basic VR compatible video. These resources were sourced within the means and time constraint of this thesis. The use of higher quality VR technology and compatible video would have further leveraged outlined effects of Fair-trade and potentially significantly affected results.

Finally, although VR technology has been around since the 90's, its increasing popularity and growth make it difficult to comprehend the full nature of its capabilities. With constant innovations and implications of AR/VR in a magnitude of sectors, its potential will continue to change and develop over time. I acknowledge that a multitude of effects and results might be related to the novelty of the technology and excitement around its application. It would be interesting to re-visit similar circumstances, after a few years, when the adoption of VR becomes more integrated in everyday life.

\section{Future Research}

Further research must be conducted in this field to better understand VR exploratory effect on Fair-trade coffee as well as potentially other specialty products. Future research should firstly take into consideration similar structured research with a larger specialty category. For example, VR's exploratory impact on consumer's purchase intention towards vegetarian or vegan products would offer a larger demographic. Comparatively, we could look at VR's 
exploratory effect on consumer's purchase intentions towards luxury products. In both cases, VR can add value whether its education or marketing of these products.

TRA being considered one of the most widely known consumer behavior models assumes that many different frameworks can be adopted or modified. Similar improvements or versions of this model including, theory planned behavior (TPB) or modifications including the amendment of subjective norms could be applied. Alternatively, another consumer behavior model such as EKB model or motivation-need theory could be modified with a similar constraint.

Lastly, researcher should address sample demographic and questionnaire in order to draw better conclusions from a wider demographic. Furthermore, develop questions in order to establish whether users have previously used VR technology or drinks coffee in order to draw better conclusions. Lastly, use higher quality VR devices and videos in order to create a more immersive experience. This would align future research among the academic standard of VR studies where the assumption that higher quality VR terminals are being used. 


\section{$\underline{\text { Appendices }}$}

Appendix A - Consent to Participate

\section{RYERSON UNIVERSITY Consent to Participate in Research}

\section{What do you see? Predicting consumer purchase intentions regarding fair-trade coffee through VR. (2018-370)}

\section{INTRODUCTION AND PURPOSE}

My name is Zachary Robichaud. I am a Graduate Student at Ryerson University working with my faculty supervisor, Professor Dr. Hong Yu in the School/Department of Retail Management. This project is being done as my culminating thesis for the Master of Science in Management program. I would like to invite you to take part in my research study, which concerns taking a look at the impact of virtual reality on consumer purchase intentions regarding fair-trade coffee through the lenses of theory reasoned action.

\section{WHAT YOU ARE BEING ASKED TO DO}

The first group will be asked to read an online definition of fair-trade coffee followed by answering an online survey. The second group will be asked to sign-up for different time slots to meet with researcher, use VR headset to watch fair-trade coffee video, and be provided with link to complete online survey.

You are being asked to voluntarily complete this on-line survey. It involves questions about your beliefs towards ethical consumption, personal values, attitude towards purchasing fair-trade coffee, general attitude towards fair-trade, purchase intentions and should take about 5-10 minutes to complete. For all of your answers to be collected you must go to the end of the survey and click 'submit survey'. This will demonstrate your full consent to participation.

\section{POTENTIAL BENEFITS}

Very little has been presented on the impacts of Virtual Reality on Theory Reasoned Action and in turn the marketing potential VR may possess on specialty products. It is hoped that the research will open a new area of research where Virtual Reality can be found as a tool to market specialty products.

\section{WHAT ARE THE POTENTIAL RISKS TO YOU}

Physical risk: Individuals using VR headsets could be "first time" users therefore little knowledge on how to use machine safely. Education of individuals on how to use VR machines safely, monitor and assist wherever necessary, and if any discomfort arises during the VR process the participant may decline to continue in study.

Furthermore, participants who experience epilepsy/seizures or any other pre-existing condition that may be affected by VR headset should not participate in study. Lastly, if 
participants feel any discomfort or side effects after use of VR, researcher will to the best of his ability help seek aid/treatment.

Psychological risk: Survey respondents may feel uncomfortable answering questions on demographics. The participant may decline to answer any question that makes them uncomfortable and continue with the rest of the survey.

Social Risk: Information being store could be accessed by unauthorized individual. The risk of unauthorized access to survey will be mitigated using secure online storage and encrypted disk drives.

Some of the survey questions may make you uncomfortable or upset or you may simply wish not to answer some questions. You are free to decline to answer any questions you do not wish to answer or stop participating at any time by closing your browser. If you close your browser before getting to the end of the survey and do not confirm your consent to participate at the end of the survey by clicking the 'submit' button your information collected up to that point will not be used.

\section{YOUR IDENTITY WILL BE ANONYMOUS AND CONFIDENTIAL}

The survey is anonymous and as such will not be collecting information that will easily identify you, like your name or other unique identifiers. Although your Internet Protocol (IP) address can be tracked through the survey platform, the researcher/s will not be collecting this information. Your IP address may be observed only to ensure that one individual is not completing the survey multiple times.

Those who participate in study involving VR headset, will have complete confidentiality in completing portion of study. Participants can access an electronic copy of research findings at https://library.ryerson.ca/info/collections-2/digital-commons/ or upon request from researcher's email.

\section{HOW YOUR INFORMATION WILL BE PROTECTED AND STORED}

This survey uses Qualtrics which is a United States of American (USA) company. Consequently, USA authorities under the provisions of the USA Freedom Act may access the survey data. If you would rather participate with an email or paperbased survey, please contact the researchers. Please note email or paper-based surveys may allow your identity to be known to the researcher/s but if you select this option your information will be kept confidential.

To further protect your information, data stored by the researcher will be password protected and/or encrypted. Only the researcher/s named in this study will have access to the data as collected. Any future publications will include collective information (i.e., aggregate data). Your individual responses (i.e. raw data) will not be shared with anyone outside of the research team.

Data will be stored through Ryerson Google Drive. Both classes of data will be stored for 2 years after research has been completed in order to fulfill any changes or challenges that may occur. The data will be used through statistical software to analyze and present findings where participants can access at https://library.ryerson.ca/info/collections-2/digitalcommons/. Data will be overwritten and deleted after period of time has elapsed. 


\section{INCENTIVE FOR PARTICIPATION}

Using the Ryerson Student Research pool, individuals in exchange for participating in the online survey will earn credit towards a bonus mark in one participating course of their choice. In exchange for participation in this (15minute/30minutes/45minute/60minute/75minute/90minute/105minute/120minute) study, participants will earn a $(0.25 \% / 0.5 \% / 0.75 \% / 1 \% / 1.25 \% / 1.50 \% / 1.75 \% / 2 \%)$ bonus towards a per-semester maximum of $2 \%$.

This study will take under 15 minutes for both groups to complete. Therefore, a merit of $0.25 \%$ will be awarded upon successful completion.

\section{YOUR RIGHTS AS A RESEARCH PARTICIPANT}

Participation in research is completely voluntary and you can withdraw your consent at any point up to clicking the submit button at the end of the survey. This can be done by closing your browser at any point to exit the study. However, because the survey is anonymous, once you click the submit button at the end of the survey the researchers will not be able to determine which survey answers belong to you so your information cannot be withdrawn after that point.

Please note that by clicking submit at the end of the study you are providing your consent for participation. By consenting to participate you are not waiving any of your legal rights as a research participant.

\section{QUESTIONS}

If you have any questions about this research, please feel free to contact the researcher/s. Zachary Robichaud (647)888-0211 zachary.robichaud@ryerson.ca Dr. Hong Yu 416-979-5000 ext. 2540 hongyu@ryerson.ca

If you have any questions about your rights or treatment as a research participant in this study, please contact the Ryerson University Research Ethics Board at rebchair@ryerson.ca (416) 979-5042. 


\section{Appendix B - Questionnaire}

\section{Introduction}

The following survey will ask you questions regarding your thoughts and behavioral intention toward purchasing fair-trade coffee. This will include: your personal values, your knowledge, general attitudes, attitudes towards purchasing fair trade coffee, the influence of people in your life and finally the intention to purchase. There are no right or wrong answers, please simply answer as accurately as possible.

The average time commitment for completing this survey is 15-20 minutes. Your responses will help practitioners gain a better understanding of fair-trade consumers.

Please understand that your participation in this research is entirely voluntary. If you decide to participate, you are free to withdraw your consent and to discontinue participation at any time without prejudice. Any information that is obtained in connection with this study will remain confidential.

\section{Survey}

For reference, here is the general definition of fair-trade:

"Fair Trade is a movement that promotes fair pay and ethical treatment for producer groups in developing countries when they export their goods to the developed world. It is regulated by a set of standards set in place by non-profit, third party Fair-trade associations who award certifications to companies that adhere to the 10 principles of fair trade".

Fair trade coffee is a type of Fair-trade product available in the marketplace.

\section{ROKEACH VALUE SCALE}

On the following pages are values listed. Each value is accompanied by a short description and a scale. Your goal is to rate each value in its level of importance to you on the following scale: $1=$ "very unimportant at all", to 7= "very important"

\begin{tabular}{|c|c|c|c|c|c|c|}
\hline 1 & 2 & 3 & 4 & 5 & 6 & 7 \\
\hline $\begin{array}{c}\text { Very } \\
\text { Unimportant }\end{array}$ & Unimportant & $\begin{array}{c}\text { Slightly } \\
\text { Unimportant }\end{array}$ & Neutral & $\begin{array}{l}\text { Slightly } \\
\text { Important }\end{array}$ & Important & $\begin{array}{c}\text { Very } \\
\text { Importan }\end{array}$ \\
\hline
\end{tabular}

\begin{tabular}{llllllll}
\hline $\begin{array}{l}\text { 1. A World at Peace (a world free of war and } \\
\text { conflict) }\end{array}$ & 1 & 2 & 3 & 4 & 5 & 6 & 7 \\
\hline 2. Intellectual (intelligent and reflective) & 1 & 2 & 3 & 4 & 5 & 6 & 7 \\
\hline 3. Courageous (standing up for your beliefs) & 1 & 2 & 3 & 4 & 5 & 6 & 7 \\
\hline
\end{tabular}




\begin{tabular}{|c|c|c|c|c|c|c|c|}
\hline 4. Helpful (working for the welfare of others) & 1 & 2 & 3 & 4 & 5 & 6 & 7 \\
\hline 5. Loyal (faithful to friends or the group) & 1 & 2 & 3 & 4 & 5 & 6 & 7 \\
\hline 6. A Comfortable Life (a prosperous life) & 1 & 2 & 3 & 4 & 5 & 6 & 7 \\
\hline 7. Obedient (dutiful, respectful) & 1 & 2 & 3 & 4 & 5 & 6 & 7 \\
\hline 8. Mature Love (Sexual and spiritual intimacy) & 1 & 2 & 3 & 4 & 5 & 6 & 7 \\
\hline $\begin{array}{l}\text { 9. A Sense of Accomplishment (a lasting } \\
\text { contribution) }\end{array}$ & 1 & 2 & 3 & 4 & 5 & 6 & 7 \\
\hline 10. Imaginative (daring and creative) & 1 & 2 & 3 & 4 & 5 & 6 & 7 \\
\hline $\begin{array}{l}\text { 11. Equality (brotherhood and equal opportunity } \\
\text { for all) }\end{array}$ & 1 & 2 & 3 & 4 & 5 & 6 & 7 \\
\hline 12. Pleasure (an enjoyable, leisurely life) & 1 & 2 & 3 & 4 & 5 & 6 & 7 \\
\hline 13. Ambitious (hardworking and aspiring) & 1 & 2 & 3 & 4 & 5 & 6 & 7 \\
\hline 14. Responsible (dependable and reliable) & 1 & 2 & 3 & 4 & 5 & 6 & 7 \\
\hline 15. Family Security (taking care of loved ones) & 1 & 2 & 3 & 4 & 5 & 6 & 7 \\
\hline 16. National Security (protection from attack) & 1 & 2 & 3 & 4 & 5 & 6 & 7 \\
\hline 17. Self-respect (self-esteem) & 1 & 2 & 3 & 4 & 5 & 6 & 7 \\
\hline 18. An exciting Life (a stimulating, active life) & 1 & 2 & 3 & 4 & 5 & 6 & 7 \\
\hline 19. Inner Harmony (Freedom from inner conflict) & 1 & 2 & 3 & 4 & 5 & 6 & 7 \\
\hline 20. Salvation (saved; eternal life) & 1 & 2 & 3 & 4 & 5 & 6 & 7 \\
\hline 21. Health (physical and mental well-being) & 1 & 2 & 3 & 4 & 5 & 6 & 7 \\
\hline $\begin{array}{l}\text { 22. A world of Beauty (beauty of nature and the } \\
\text { arts) }\end{array}$ & 1 & 2 & 3 & 4 & 5 & 6 & 7 \\
\hline 23. True Friendship (close companionship) & 1 & 2 & 3 & 4 & 5 & 6 & 7 \\
\hline 24. Freedom (independence and free choice) & 1 & 2 & 3 & 4 & 5 & 6 & 7 \\
\hline 25. Logical (consistent, rational) & 1 & 2 & 3 & 4 & 5 & 6 & 7 \\
\hline 26. Self-controlled (Restrained, self-disciplined) & 1 & 2 & 3 & 4 & 5 & 6 & 7 \\
\hline 27. Honest (sincere and truthful) & 1 & 2 & 3 & 4 & 5 & 6 & 7 \\
\hline 28. Capable (competent, effective) & 1 & 2 & 3 & 4 & 5 & 6 & 7 \\
\hline 29. Polite (courteous and well-mannered) & 1 & 2 & 3 & 4 & 5 & 6 & 7 \\
\hline 30. Social Recognition (respect and admiration & 1 & 2 & 3 & 4 & 5 & 6 & 7 \\
\hline 31. Clean (neat and tidy) & 1 & 2 & 3 & 4 & 5 & 6 & 7 \\
\hline 32. Forgiving (willing to pardon others) & 1 & 2 & 3 & 4 & 5 & 6 & 7 \\
\hline 33. Broad-minded (open-minded) & 1 & 2 & 3 & 4 & 5 & 6 & 7 \\
\hline
\end{tabular}




\begin{tabular}{llllllll}
\hline 34. Independent (self-reliant, self-sufficient) & 1 & 2 & 3 & 4 & 5 & 6 & 7 \\
\hline 35. Wisdom (a mature understanding of life) & 1 & 2 & 3 & 4 & 5 & 6 & 7 \\
\hline 36. Loving (affectionate and tender) & 1 & 2 & 3 & 4 & 5 & 6 & 7 \\
\hline
\end{tabular}

\section{Knowledge of fair-trade}

The set of questions are about your knowledge of the fair-trade process in general. Please indicate your agreement with the following statements by selecting a number from the scale.

$\begin{array}{ccccccc}1 & 2 & 3 & 4 & 5 & 6 & 7 \\ \text { Strongly } & \text { Disagree } & \text { Slightly } & \text { Neutral } & \text { Slightly } & \text { Agree } & \text { Strongly } \\ \text { Disagree } & & \text { Disagree } & & \text { Agree } & & \text { Agree }\end{array}$

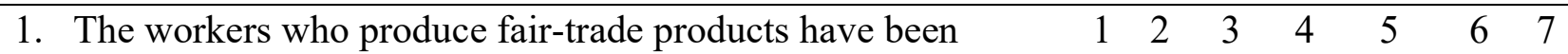
treated with respect

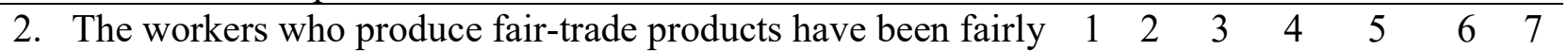
paid

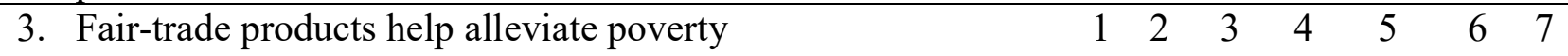

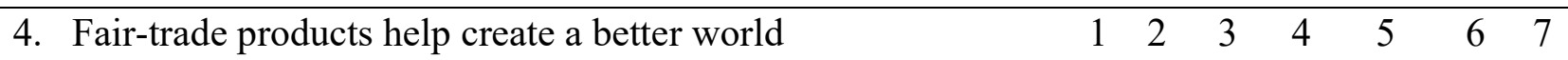

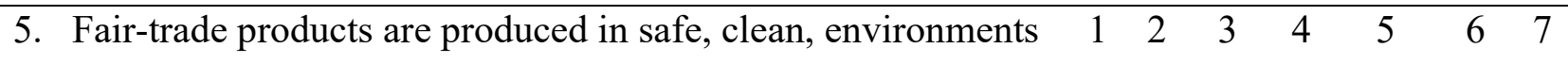

6. Environmentally sustainable practices are followed during the $1 \begin{array}{llllllll} & 1 & 2 & 3 & 4 & 5 & 6 & 7\end{array}$ production of fair-trade products

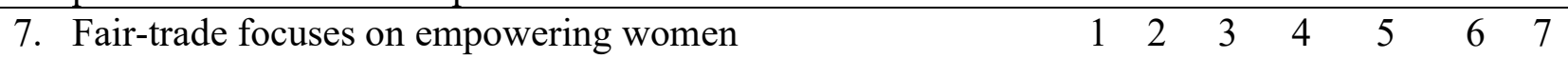

\section{General attitude towards fair-trade}

The set of questions are about your general attitude towards fair-trade. Please indicate your agreement with the following statements by selecting a number from the scale.
1
Strongly
Disagree
2
3
4
56
$6 \quad 7$
Slightly
Neutral
Slightly
Agree Strongly
Agree
Agree

1. Fair-trade is too much like charity

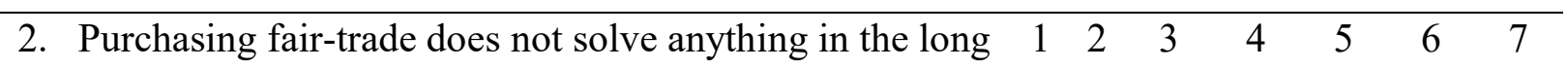
run. It just eases your conscience

\begin{tabular}{|c|c|c|c|c|c|c|}
\hline 3. Fair-trade lacks credibility & 12 & 3 & 4 & 5 & 6 & 7 \\
\hline $\begin{array}{l}\text { 4. Fair-trade makes me think of a colonial attitude by } \\
\text { means of which we impose our norms to others }\end{array}$ & 12 & 3 & 4 & 5 & 6 & 7 \\
\hline
\end{tabular}


5. The fair-trade principle cannot work on a larger scale $\quad \begin{array}{llllllll}1 & 2 & 3 & 4 & 5 & 6 & 7\end{array}$

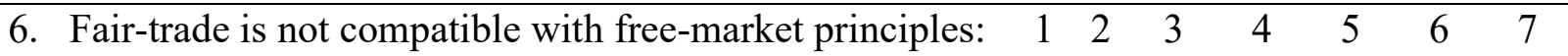
it is impossible to trade fairly and be profitable

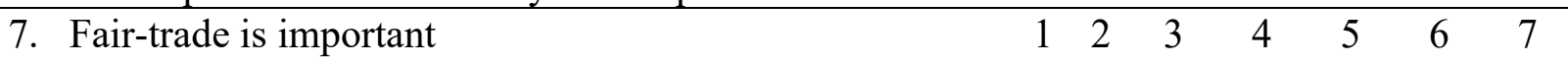

8. Fair-trade ought to be a generalized way of trading (the $\quad \begin{array}{llllllll} & 1 & 2 & 3 & 4 & 5 & 6 & 7\end{array}$ benchmark) and not an alternative way (the exception)

9. I am concerned about the fair-trade issue $\quad \begin{array}{llllllll} & 2 & 3 & 4 & 5 & 6 & 7\end{array}$

\section{Attitudes towards purchasing fair-trade coffee.}

We want to find out what characteristics would be important to you when purchasing fair-trade coffee. Pease select a number from the following scale to best describe your feelings about each characteristic to you.
1
Very
2
3
Unimportant
Slightly
4
5
6
7
Unimportant
Unimportant
Neutral
Slightly Important
Very
Important
Important

1. Fair-trade coffee is healthier.

$\begin{array}{lllllll}1 & 2 & 3 & 4 & 5 & 6 & 7\end{array}$

2. Fair-trade coffee is tastier.

$\begin{array}{lllllll}1 & 2 & 3 & 4 & 5 & 6 & 7\end{array}$

3. Fair-trade coffee is of better quality.

$\begin{array}{lllllll}1 & 2 & 3 & 4 & 5 & 6 & 7\end{array}$

4. Fair-trade coffee should not be more expensive.

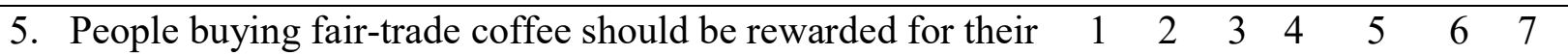
good behaviors by not paying extra.

6. The purchase of free-trade coffee requires an additional $\quad \begin{array}{lllllll}1 & 2 & 3 & 4 & 5 & 6 & 7\end{array}$ effort compared to regular coffee.
7. Fair-trade coffee should be less expensive

$\begin{array}{lllllll}1 & 2 & 3 & 4 & 5 & 6 & 7\end{array}$

Please select a number from the following scale to indicate your agreement with following statements
1
Strongly
2
3
Disagree
Disagree
Slightly
4
Disagree
Neutral
5
6
Agree
7
Slightly
Agree
Strongly
Agree

1. Fair-trade coffee is healthier.

$\begin{array}{lllllll}1 & 2 & 3 & 4 & 5 & 6 & 7\end{array}$

2. Fair-trade coffee is tastier.

$\begin{array}{lllllll}1 & 2 & 3 & 4 & 5 & 6 & 7\end{array}$

3. Fair-trade coffee is of better quality.

$\begin{array}{lllllll}1 & 2 & 3 & 4 & 5 & 6 & 7\end{array}$




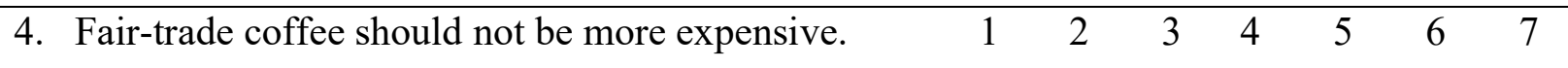

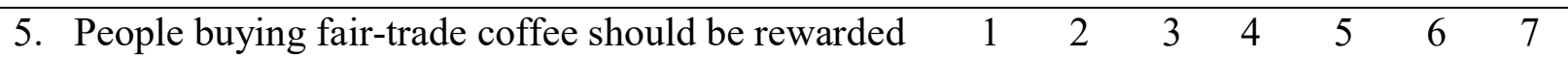
for their good behaviors by not paying extra.

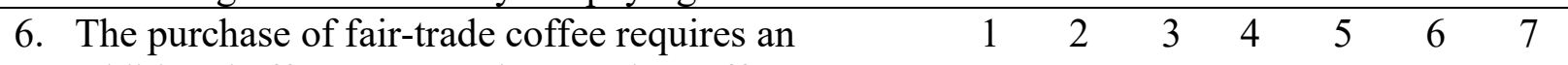
additional effort compared to regular coffee.

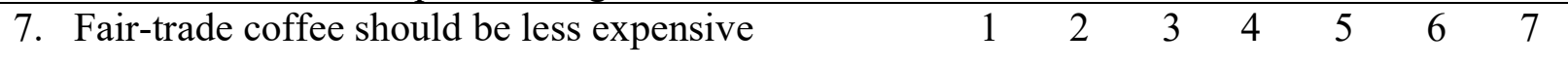

\section{Subjective Norm}

These set of questions are about the influence of people in your life. Please indicate your agreement with the following statement.

\begin{tabular}{|c|c|c|c|c|c|c|c|c|c|c|}
\hline $\begin{array}{c}1 \\
\text { Strongly } \\
\text { Disagree }\end{array}$ & $\begin{array}{c}2 \\
\text { Disagree }\end{array}$ & $\begin{array}{c}3 \\
\text { Slightly } \\
\text { Disagree }\end{array}$ & $\begin{array}{c}4 \\
\text { Neutral }\end{array}$ & $\begin{array}{c}5 \\
\text { Slightly } \\
\text { Agree }\end{array}$ & & & $\begin{array}{l}6 \\
\text { Agree }\end{array}$ & & \multicolumn{2}{|c|}{$\begin{array}{c}7 \\
\text { Strongly } \\
\text { Agree }\end{array}$} \\
\hline \multicolumn{4}{|c|}{$\begin{array}{l}\text { 1. My friends think I should purchase fair-trade } \\
\text { coffee. }\end{array}$} & 1 & 2 & 3 & 4 & 5 & & 7 \\
\hline \multicolumn{4}{|c|}{$\begin{array}{l}\text { 2. My family thinks I should purchase fair-trade } \\
\text { coffee. }\end{array}$} & 1 & 2 & 3 & 4 & 5 & & 7 \\
\hline \multicolumn{4}{|c|}{$\begin{array}{l}\text { 3. My colleagues think I should purchase fair-trade } \\
\text { coffee }\end{array}$} & 1 & 2 & 3 & 4 & 5 & & 7 \\
\hline \multicolumn{4}{|c|}{$\begin{array}{l}\text { 4. My classmates think I should purchase fair-trade } \\
\text { coffee }\end{array}$} & 1 & 2 & 3 & 4 & 5 & & 7 \\
\hline & 2 & 3 & 4 & \multicolumn{2}{|l|}{5} & \multicolumn{3}{|c|}{6} & \multicolumn{2}{|r|}{7} \\
\hline $\begin{array}{l}\text { Very } \\
\text { Unlikely }\end{array}$ & Unlikely & $\begin{array}{l}\text { Somewhat } \\
\text { Unlikely }\end{array}$ & Undecided & \multicolumn{2}{|c|}{$\begin{array}{l}\text { Somewhat } \\
\text { Likely }\end{array}$} & \multicolumn{3}{|c|}{ Likely } & \multicolumn{2}{|c|}{$\begin{array}{l}\text { Very } \\
\text { Likely }\end{array}$} \\
\hline \multicolumn{4}{|c|}{$\begin{array}{l}\text { 1. My friends think I should purchase fair-trade } \\
\text { coffee }\end{array}$} & 1 & 2 & 3 & 4 & 5 & 6 & 7 \\
\hline 2. $\begin{array}{l}\mathrm{M} \\
\mathrm{cc}\end{array}$ & mily thinks & should purch & se fair-trade & 1 & 2 & 3 & 4 & 5 & 6 & 7 \\
\hline 3. $\begin{array}{l}\mathrm{M} \\
\mathrm{cc}\end{array}$ & lleagues thi & I should pu & chase fair-trade & 1 & 2 & 3 & 4 & 5 & 6 & 7 \\
\hline 4. $\begin{array}{l}\mathrm{M} \\
\mathrm{cc}\end{array}$ & assmates thi & I should pu & chase fair-trade & 1 & 2 & 3 & 4 & 5 & 6 & 7 \\
\hline
\end{tabular}

\section{Intention}


Rate your level of agreement with the statement

\begin{tabular}{|c|c|c|c|c|c|c|c|c|c|c|}
\hline $\begin{array}{c}1 \\
\text { Strongly } \\
\text { Disagree }\end{array}$ & $\begin{array}{l}2 \\
\text { Disagree }\end{array}$ & $\begin{array}{c}3 \\
\text { Slightly } \\
\text { Disagree }\end{array}$ & $\begin{array}{c}4 \\
\text { Neutral }\end{array}$ & \multicolumn{2}{|c|}{$\begin{array}{c}5 \\
\text { Slightly } \\
\text { Agree }\end{array}$} & \multicolumn{3}{|c|}{$\begin{array}{c}6 \\
\text { Agree }\end{array}$} & \multicolumn{2}{|c|}{$\begin{array}{c}7 \\
\text { Strongly } \\
\text { Agree }\end{array}$} \\
\hline \multicolumn{4}{|c|}{$\begin{array}{l}\text { 1. I intend to purchase fair-trade coffee within the } \\
\text { next month. }\end{array}$} & 1 & 2 & 3 & 4 & 5 & 6 & 7 \\
\hline \multicolumn{4}{|c|}{$\begin{array}{l}\text { 2. I plan to purchase fair-trade coffee within the } \\
\text { next month. }\end{array}$} & 1 & 2 & 3 & 4 & 5 & 6 & 7 \\
\hline \multicolumn{4}{|c|}{$\begin{array}{l}\text { 3. I will purchase fair-trade coffee within the next } \\
\text { month. }\end{array}$} & 1 & 2 & 3 & 4 & 5 & 6 & 7 \\
\hline
\end{tabular}

\section{Demographics}

Which gender do you identify most with?

o Male

- Female

○ Other

What is your age?

$\circ$ Under 18

○ $18-24$

○ $25-34$

○ $35-44$

○ $45-54$

○ Above 54

What is you highest qualification?

- Less than high school diploma

- High school diploma or equivalent degree

- Some postsecondary education

- Bachelor's degree

- Master's degree

- Ph.D or equivalent degree

What is your current employment status?

○ Full-time employment

- Part-time employment

○ Unemployed 
○ Retired

Which income group did your household gross annual income fall under in $2018 ?$

○ Less than $\$ 20,000$

○ $\$ 21,000-\$ 40,000$

- $\$ 41,000$ to $\$ 60,000$

○ $\$ 61,000$ to $\$ 80,000$

- $\$ 81,000$ to $\$ 100,000$

○ Above $\$ 100,000$ 


\section{Ryerson Ethics Board}

To: Zachary Robichaud

Ted Rogers School of Management

Re: REB 2018-370: What do you see? Predicting consumer purchase intentions regarding fair-trade coffee through VR.

Date: November 21, 2018

Dear Zachary Robichaud,

The review of your protocol REB File REB 2018-370 is now complete. The project has been approved for a one year period. Please note that before proceeding with your project, compliance with other required University approvals/certifications, institutional requirements, or governmental authorizations may be required.

This approval may be extended after one year upon request. Please be advised that if the project is not renewed, approval will expire and no more research involving humans may take place. If this is a funded project, access to research funds may also be affected.

Please note that REB approval policies require that you adhere strictly to the protocol as last reviewed by the REB and that any modifications must be approved by the Board before they can be implemented. Adverse or unexpected events must be reported to the REB as soon as possible with an indication from the Principal Investigator as to how, in the view of the Principal Investigator, these events affect the continuation of the protocol.

Finally, if research subjects are in the care of a health facility, at a school, or other institution or community organization, it is the responsibility of the Principal Investigator to ensure that the ethical guidelines and approvals of those facilities or institutions are obtained and filed with the REB prior to the initiation of any research.

Please quote your REB file number (REB 2018-370) on future correspondence.

Congratulations and best of luck in conducting your research.

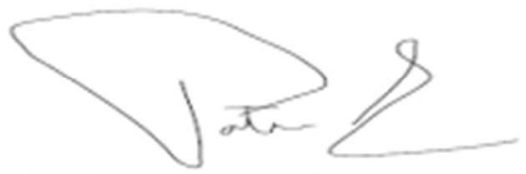

Dr. Patrizia Albanese, $\mathrm{PhD}$

Chair, Ryerson University Research Ethics Board

The Following protocol attachments have been reviewed and approved. 


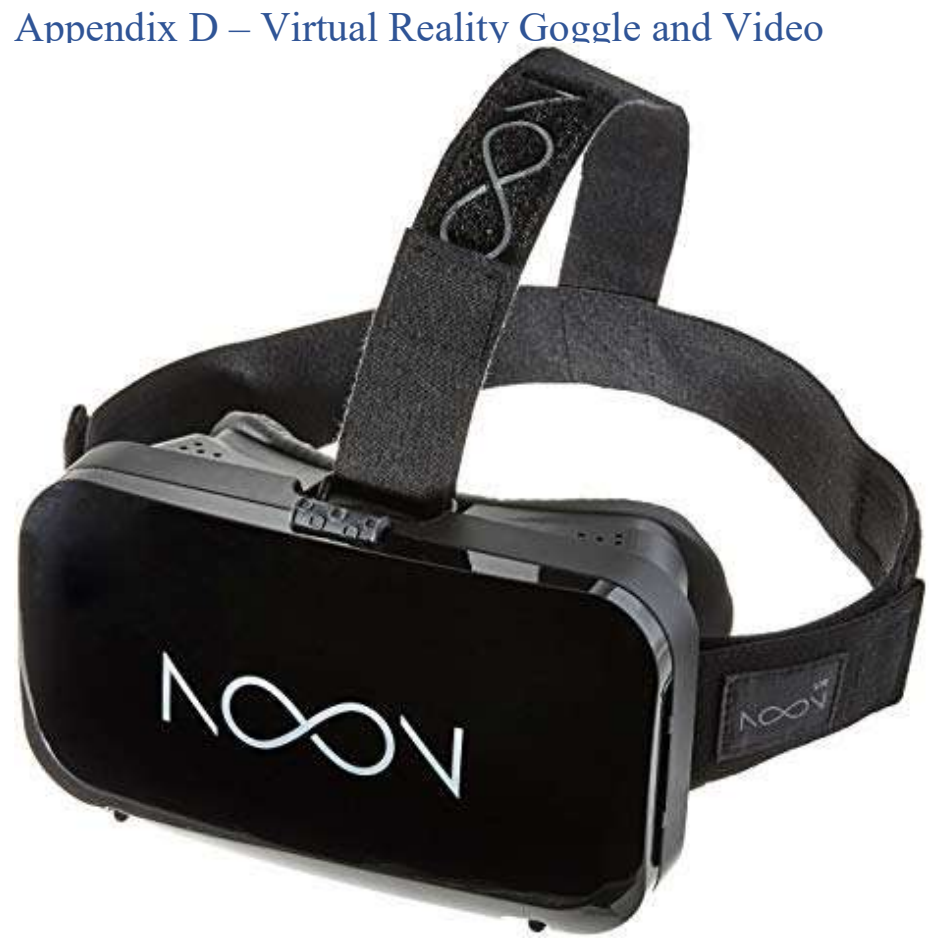




\section{$\underline{\text { Work cited }}$}

About the global Fair-trade system. (2019). Fairtrade Canada. Retrieved from:

http://fairtrade.ca/en-CA/What-is-Fairtrade/Who-is-Fairtrade-Canada/About-the-globalFairtrade-system

Abulrub, A. H. G., Attridge, A. N., \& Williams, M. A. (2011, April). Virtual reality in engineering education: The future of creative learning. In 2011 IEEE global engineering education conference (EDUCON) (pp. 751-757). IEEE.

Ajzen, I., \& Fishbein, M. (1972). Attitudes and normative beliefs as factors influencing behavioral intentions. Journal of Personality and Social Psychology, 21(1), 1-9.

Ajzen, I., \& Fishbein, M. (1977). Attitude-behavior relations: A theoretical analysis and review of empirical research. Psychological bulletin, 84(5), 888.

Ajzen, I., \& Fishbein, M. (1980). Understanding attitudes and predicting social behaviour.

Ajzen, I. (2001). Nature and operation of attitudes. Annual Review of Psychology, 52, 27-58.

Alwin, D. F., \& Krosnick, J. A. (1985). The measurement of values in surveys: A comparison of ratings and rankings. Public Opinion Quarterly, 49(4), 535-552.Anderson, W. Thomas Jr. and William H. Cunningham (1972), "The Socially Conscious Consumer," Journal of Marketing, 36 (July), 23-31.

Arakji, R., \& Lang, K. (2008). Avatar business value analysis: a method for the evaluation of business value creation in virtual commerce.

Bhatt, G. (2004). Bringing virtual reality for commercial Web sites. International Journal of Human-Computer Studies, 60(1), 1-15.

Barnes, S., \& Mattsson, J. (2008). Brand value in virtual worlds: an axiological approach. Journal of Electronic Commerce Research, 9(3), 195. 
Barnes, N. G., \& Mattson, E. (2008). Still setting the pace in social media: The first longitudinal study of usage by the largest US charities. University of Massachusetts Dartmouth Center for Marketing Research.

Bentler, P. M., \& Speckart, G. (1979). Models of attitude-behavior relations. Psychological review, 86(5), 452 .

Berry, H., \& McEachern, M. (2005). Informing ethical consumers.

Bhatt, G. (2004). Bringing virtual reality for commercial Web sites. International Journal of Human-Computer Studies, 60 (1) (2004), pp. 1-15

Biocca, F. (1997). The cyborg's dilemma: Progressive embodiment in virtual environments. Journal of computer-mediated communication, 3(2), JCMC324.

Biocca, Frank, Terry M. Daugherty, Hairong Li, and Zoo-Hyun Chae (2001), "Effect of Visual Sensory Immersion on Product Knowledge, Attitude toward the Product and Purchase Intention," In Frank Biocca (Ed.), Proceedings of the Experiential E-commerce Conference, [CD-ROM], East Lansing, MI.

Bird, K., \& Hughes, D. R. (1997). Ethical consumerism: The case of "Fairly-Traded" coffee. Business ethics: A European review, 6(3), 159-167.

Blackman, A. (2018). What Are Your Personal Values? How to Define \& Live by Them. Retrieved July 23, 2019, from Business Envato Tuts+ website: https://business.tutsplus.com/tutorials/what-are-personal-values--cms-31561

Blaikie, N. (2010). Designing social research (2nd ed.). polity.

Blaikie, N. (2007). Approaches to Social Enquiry: Advancing Knowledge, 2nd edn. Cambridge: Polity Press. 
Blümel, E., \& Haase, T. (2009, September). Virtual reality platforms for education and training in industry. In East European Conference on Advances in Databases and Information Systems (pp. 1-7). Springer, Berlin, Heidelberg.

Boersma, F. V. (2009). The urgency and necessity of a different type of market: the perspective of producers organized within the fair trade market. Journal of Business Ethics, 86(1), 5161.

Bolton, D. (2016). Why virtual reality education is the next frontier for classrooms. Arc from Applause. Retrieved from https://arc.applause.com/2016/06/30/virtualrealityeducation/

Boyd, B., \& Wandersman, A. (1991). Predicting Undergraduate Condom Use with the Fishbein and Ajzen and the Triandis Attitude-Behavior Models: Implications for Public Health Interventions 1. Journal of Applied Social Psychology, 21(22), 1810-1830.

Budruk, M., White, D. D., Wodrich, J. A., \& Van Riper, C. J. (2008). Connecting visitors to people and place: Visitors' perceptions of authenticity at Canyon de Chelly National Monument, Arizona. Journal of Heritage Tourism, 3(3), 185-202.

Buhalis, D., \& Law, R. (2008). Progress in information technology and tourism management: 20 years on and 10 years after the Internet-The state of eTourism research. Tourism management, 29(4), 609-623.

Burch, M., Weiskopf, D., \& Ertl, T. (2017). Visualization of eye tracking data: A taxonomy and survey. In Computer Graphics Forum (Vol. 36, No. 8, pp. 260-284).

Burke, R. R. (1998). Real shopping in a virtual store. Sense and Respond: Capturing the Value in the Network Era, Harvard Business School, Boston, MA, 35-41.

Carrigan, M., \& Attalla, A. (2001). The myth of the ethical consumer-do ethics matter in purchase behaviour?. Journal of consumer marketing, 18(7), 560-578. 
Castelvecchi, D. (2016). Can we open the black box of AI?. Nature News, 538(7623), 20.

Carrigan, M., \& Attalla, A. (2001). The myth of the ethical consumer-do ethics matter in purchase behaviour?. Journal of consumer marketing, 18(7), 560-578.

Cheong, R. (1995). The virtual threat to travel and tourism. Tourism Management, 16(6), $417-422$.

Cherrier, H. (2007). Ethical consumption practices: co-production of self-expression and social recognition. Journal of Consumer Behaviour: An International Research Review, 6(5), 321-335.

CGS. (2019, January 10). CGS Survey Reveals Sustainability Is Driving Demand and Customer Loyalty. Retrieved August 27, 2019, from GlobeNewswire News Room website: http://www.globenewswire.com/news-release/2019/01/10/1686144/0/en/CGS-SurveyReveals-Sustainability-Is-Driving-Demand-and-Customer-Loyalty.html

Chhabra, D. (2005). Defining authenticity and its determinants: toward an authenticity flow model J. Travel Res., 44 (2005), pp. 64-73

Cobb-Walgren, C. J., Ruble, C. A., \& Donthu, N. (1995). Brand equity, brand preference, and purchase intent. Journal of advertising, 24(3), 25-40.

Cooper, K. (2017, September 8). VR will be an essential part of retail's future. Retrieved April 24, 2018, from https://venturebeat.com/2017/09/08/vr-will-be-an-essential-part-of-thefuture-of-retail/

Cranfield, J., Henson, S., Northey, J., \& Masakure, O. (2010). An assessment of consumer preference for fair trade coffee in Toronto and Vancouver. Agribusiness, 26(2), 307-325.

Creswell, J.,W. (2007). Research design. Qualitative and mixed methods approaches. London: Sage. 
d'Astous, A. and Mathieu, S. (2008), "Inciting consumers to buy fairly-traded products: a field experiment”, Journal of Consumer Marketing, Vol. 25 No. 3, pp. 149-57.

Davis, L.E., Ajzen, I., Saunders, J., \& Williams, T. (2002). The decision of African American students to complete high school: An application of the theory of planned behavior. Journal of Educational Psychology, 94(4), 810-819.

De Devitiis, B., D'Alessio, M., \& Maietta, O. W. (2008). A comparative analysis of the purchase motivations of Fair Trade products: the impact of social capital (No. 725-201649573).Diamantopoulos, A., Schlegelmilch, B. B., Sinkovics, R. R., \& Bohlen, G. M. (2003). Can socio-demographics still play a role in profiling green consumers? A review of the evidence and an empirical investigation. Journal of Business research, 56(6), 465-480.

De Leeuw, A., Valois, P., Morin, A. J. S., \& Schmidt, P. (2014). Gender differences in psychosocial determinants of university students' intention to buy fair trade products. Journal of Consumer Policy, 37, 485-505.

De Pelsmacker, P., Driesen, L., \& Rayp, G. (2003). Are fair trade labels good business? Ethics and coffee buying intentions. Journal of Consumer Affairs, 39(2).

De Pelsmacker, P., Driesen, L., \& Rayp, G. (2005). Do consumers care about ethics? Willingness to pay for fair-trade coffee. Journal of consumer affairs, 39(2), 363-385.

De Pelsmacker, P. and Janssens, W. (2007), “A model for fair trade buying behaviour: the role of perceived quantity and quality of information and of product-specific attitudes", Journal of Business Ethics, Vol. 75 No. 4, pp. 361-80.

Diamantopoulos, A., Schlegelmilch, B. B., Sinkovics, R. R., \& Bohlen, G. M. (2003). Can sociodemographics still play a role in profiling green consumers? A review of the evidence and an empirical investigation. Journal of Business research, 56(6), 465-480.Doane, D. (2001). 
Taking flight: The rapid growth of ethical consumerism. London: New Economics Foundation, 1.

Dickson, M. A. (2000). Personal values, beliefs, knowledge, and attitudes relating to intentions to purchase apparel from socially responsible businesses. Clothing and Textiles Research Journal, 18(1), 19-30.

Doane, D., \& MacGillivray, A. (2001). Economic Sustainability: The business of staying in business. New Economics Foundation, 1-52.

Domina, T., Lee, S. E., \& MacGillivray, M. (2012). Understanding factors affecting consumer intention to shop in a virtual world. Journal of retailing and consumer services, 19(6), 613620.

Doran, C. (2009). The role of personal values in Fair Trade consumption. Journal of Business Ethics, 84, 549-563.

Doran, C. (2010). Fair Trade consumption: In support of the out-group. Journal of Business Ethics, 95, 527-541.

Egger, R., \& Buhalis, D. (2008). eTourism, Case Studies. Butteworth Heinemann.

The Fairtrade Foundation Annual Report and Financial Statements. (2018). The Fairtrade Foundation. Retrieved from:

https://www.fairtrade.net/fileadmin/user_upload/content/2009/about_us/annual_reports/20 17-18_FI_AnnualReport.pdf

Ferrell, O. C., \& Gresham, L. G. (1985). A contingency framework for understanding ethical decision making in marketing. Journal of marketing, 49(3), 87-96. 
Finlay, K. A., Trafimow, D., \& Moroi, E. (1999). The Importance of Subjective Norms on

Intentions to Perform Health Behaviors. [Article]. Journal of Applied Social Psychology, 29(11), 2381-2393.

Garris, R., Ahlers, R., \& Driskell, J. E. (2002). Games, motivation, and learning: A research and practice model.

Gen Z Is Set to Outnumber Millennials Within a Year. (2019). Bloomberg.Com. Retrieved from https://www.bloomberg.com/news/articles/2018-08-20/gen-z-to-outnumber-millennialswithin-a-year-demographic-trends

Getting serious. (2007, December 8). The Economist. Retrieved from https://www.economist.com/technology-quarterly/2007/12/08/getting-serious

Gorsuch, R. L., \& Ortberg, J. (1983). Moral obligation and attitudes: Their relation to behavioral intentions. Journal of Personality and Social Psychology, 44(5), 1025.

Grabowski, A., \& Jankowski, J. (2015). Virtual reality-based pilot training for underground coal miners. Safety science, $72,310-314$.

Green Generation: Millennials Say Sustainability Is a Shopping Priority. (2018). Retrieved April 24, 2018, from http://www.nielsen.com/ca/en/insights/news/2015/green-generationmillennials-say-sustainability-is-a-shopping-priority

Grønflaten, Ø. (2009). Predicting travelers' choice of information sources and information channels. Journal of Travel Research, 48(2), 230-244.

Guba, E. G. (1990). The paradigm dialog. In Alternative Paradigms Conference, Mar, 1989, Indiana U, School of Education, San Francisco, CA, US. Sage Publications, Inc.

Gutierrez, M., Vexo, F., \& Thalmann, D. (2008). Stepping into virtual reality. London: Springer. 
Guttentag, D. A. (2010). Virtual reality: Applications and implications for tourism. Tourism Management, 31(5), 637-651.

Hair, J. F., Anderson, R. E., Tatham, R. L., \& William, C. (2010). Multivariate data analysis (7th ed.). Upper Saddle River, NJ: Prentice-Hall Inc.

Hale, J. L., Householder, B. J., \& Greene, K. L. (2002). The theory of reasoned action. The persuasion handbook: Developments in theory and practice, 14, 259-286.

Harrison, R., Newholm, T.,Shaw, D., (2005). The Ethical Consumer. Sage: London.

Hassouneh, D., \& Brengman, M. (2015). Retailing in social virtual worlds: developing a typology of virtual store atmospherics. Journal of Electronic Commerce Research, 16(3), 218.

Hira, A., \& Ferrie, J. (2006). Fair trade: Three key challenges for reaching the mainstream. Journal of business ethics, 63(2), 107-118.

How Much Financial Influence Does Gen Z Have? (2019). Retrieved August 27, 2019, from https://www.forbes.com/sites/jefffromm/2018/01/10/what-you-need-to-know-about-thefinancial-impact-of-gen-z-influence/\#14bdc41756fc

How to perform a Multiple Regression Analysis in SPSS Statistics | Laerd Statistics. (2019). Retrieved July 23, 2019, from https://statistics.laerd.com/spss-tutorials/multiple-regressionusing-spss-statistics.php

Huang, Y. C., Backman, K. F., Backman, S. J., \& Chang, L. L. (2016). Exploring the implications of virtual reality technology in tourism marketing: An integrated research framework. International Journal of Tourism Research, 18(2), 116-128.

Hunt, S. D., \& Vitell, S. J. (1993). The general theory of marketing ethics: A retrospective and revision. Ethics in marketing, (775-84). 
Jacobson, J., Ellis, M., Ellis, S., \& Seethaler, L. (2005, June). Immersive displays for education using CaveUT. In EdMedia+ Innovate Learning (pp. 4525-4530). Association for the Advancement of Computing in Education (AACE).

Jacobson, J., \& Holden, L. (2005). The virtual Egyptian temple. World Conference on Educational Multimedia Hypermedia \& Telecommunications, Montreal, Canada.

Jaffee, S. R., Caspi, A., Moffitt, T. E., \& Taylor, A. (2004). Physical maltreatment victim to antisocial child: evidence of an environmentally mediated process. Journal of abnormal psychology, 113(1), 44.

Kidwell, B., \& Jewell, R.D. (2003). An examination of perceived behavioral control: Internal and external influences on intention. Psychology \& Marketing, 20(7), 625-642.

Kim, T., \& Biocca, F. (1997). Telepresence via television: Two dimensions of telepresence may have different connections to memory and persuasion. Journal of Computer-Mediated Communication, 3(2).

Kim, J., \& Forsythe, S. (2008). Adoption of virtual try-on technology for online apparel shopping. Journal of Interactive Marketing, 22(2), 45-59.

Klein LR (2003) Creating virtual product experiences: the role of telepresence. J Interact Market $17: 41-55$.

Korolov, M. (2014). The real risks of virtual reality. Risk Management, 61(8), 20-24.

Langer, E. J. (1989). Mindfulness. Reading, MA, US.

Lee, K. (2011) The green purchase behavior of Hong Kong young consumers: the role of peer influence, local environmental involvement, and concrete environmental knowledge. Journal of International Consumer Marketing, 23, 21-44. 
Leite, W. L., Svinicki, M., \& Shi, Y. (2010). Attempted validation of the scores of the VARK: Learning styles inventory with multitrait-multimethod confirmatory factor analysis models. Educational and Psychological Measurement, 70(2), 323-339

Littrell, M. A., \& Dickson, M. A. (1999). Social responsibility in the global market: Fair trade of cultural products. Sage publications.

Li, H., Daugherty, T., \& Biocca, F. (2001). Characteristics of virtual experience in electronic commerce: A protocol analysis. Journal of Interactive Marketing, 15(3), 13-30.

Liu, S.-Q. (2005). A theoretic discussion of tourism e-commerce. In Proceedings of the 7th International Conference on Electronic Commerce (pp. 1-5). Xi'an, China: ACM Press Liu, W., \& Aaker, J. (2008). The happiness of giving: The time-ask effect. Journal of consumer research, 35(3), 543-557.

Loureiro, M. L., McCluskey, J. J., \& Mittelhammer, R. C. (2002). Will consumers pay a premium for eco-labeled apples?. Journal of Consumer Affairs, 36(2), 203-219.

Luckerson, V. (2014). Facebook Buying Oculus Virtual-Reality Company for \$2 Billion. Retrieved November, 13, 2014.

Lunday, J., \& Barry, M. (2004). Connecting the dots between intentions, action and results: A multi-pronged approach to ethical decision making. Ivey Business Journal, March/April, 16.

Ma, Y. J., Littrell, M. A., \& Niehm, L. (2012). Young female consumers' intentions Toward fair trade consumption. International Journal of Retail \& Distribution Management, 40(1), 41-63.

Maignan, I., \& Ferrell, O. C. (2001). Corporate citizenship as a marketing instrument-Concepts, evidence and research directions. European journal of marketing, 35(3/4), 457-484. 
Maietta, O. W. (2003, June). The hedonic price of fair trade coffee for the Italian consumer. In Proceedings of the International Conference on Agricultural Policy Reform and the WTO: where are we heading.

Mennecke, B. E., Terando, W. D., Janvrin, D. J., \& Dilla, W. N. (2007). It's just a game, or is it? Real money, real income, and real taxes in virtual worlds. The Communications of the Association for Information Systems, 20(15), 134-141.

Micheletti, M. (2003). Shopping with and for Virtues. In Political virtue and shopping (pp. 149168). Palgrave Macmillan, New York.

Micheletti, M., Stolle, D. and Follesdal, A. (2004), "Politics, Products and Markets, Exploring Political Consumerism Past and Present”, New Brunswick: Transaction Publishers

Mikropoulos, T. A. (2006). Presence: a unique characteristic in educational virtual environments. Virtual Reality, 10, 197-206.

Mills, S., \& Noyes, J. (1999). Virtual reality: an overview of user-related design issues revised paper for special issue on "Virtual reality: User Issues" in Interacting with Computers, May 1998. Interacting with computers, 11(4), 375-386.

Mori, (2000). European Attitudes towards Corporate Social Responsibility. Research for CSR Europe. London: MORI.

Murray, S. F., \& Pearson, S. C. (2006). Maternity referral systems in developing countries: current knowledge and future research needs. Social science \& medicine, 62(9), 22052215 . 
Najafipour, A. A., Heidari, M., \& Foroozanfar, M. H. (2014). Describing the Virtual Reality and Virtual Tourist Community: Applications and Implications for Tourism Industry. Kuwait Chapter of Arabian Journal of Business and Management Review, 33(2572), 1-12.

Newholm, T., \& Shaw, D. (2007). Studying the ethical consumer: A review of research. Journal of Consumer Behaviour: an international research review, 6(5), 253-270.

Nicholls, A.: 2002, 'Strategic Options in Fair Trade Retailing', International Journal of Retail and Distribution Management 30(1), 6-17.

Nicholls, A. and Lee, N. (2006), "Purchase decision-making in fair trade and the ethical purchase 'gap': ‘is there a fair trade twix?’”, Journal of Strategic Marketing, Vol. 14 No. 4, pp. 36986.

Nielsen. (2016). Green Generation: Millennials Say Sustainability Is a Shopping Priority. Retrieved June 13, 2019, from http://www.nielsen.com/us/en/insights/news/2015/greengeneration-millennials-say-sustainability-is-a-shopping-priority

Nilsson, H., Tunçer, B., \& Thidell, Å. (2004). The use of eco-labeling like initiatives on food products to promote quality assurance — is there enough credibility? Journal of Cleaner production, 12(5), 517-526.

Oberseder, M., Schlegelmilch, B.B., Gruber, V., 2011. Why don't consumers care about CSR?': a qualitative study exploring the role of CSR in consumption decisions. J. Bus. Ethics 104, 449-460.

Ott, M., \& Tavella, M. (2009). A contribution to the understanding of what makes young students genuinely engaged in computer-based learning tasks. Procedia-Social and Behavioral Sciences, 1(1), 184-188. 
Pedregal, V. D., \& Ozcaglar-Toulouse, N. (2011). Why does not everybody purchase fair trade products? The question of the fairness of fair-trade products' consumption for consumers 1 . International journal of consumer studies, 35(6), 655-660.

Petrov, V., Dohler, M., \& Yanikomeroglu, H. (2019). Future of ultra-dense networks beyond 5G: harnessing heterogeneous moving cells. IEEE Communications Magazine.

Pimentel, K., Teixeira, K., \& Jamet, D. (1994). La réalité virtuelle...: de l'autre côté du miroir. Ed. Addison-Wesley.

Pires, S. M., Evers, E. G., van Pelt, W., Ayers, T., Scallan, E., Angulo, F. J., ... \& Hald, T. (2009). Attributing the human disease burden of foodborne infections to specific sources. Foodborne Pathogens and Disease, 6(4), 417-424.

Raats, M. M., Shepherd, R., \& Sparks, P. (1995). Including moral dimensions of choice within the structure of the theory of planned behavior. Journal of Applied Social Psychology, 25(6), 484-494.

Rebenitsch, L., \& Owen, C. (2016). Review on cybersickness in applications and visual displays. Virtual Reality, 20(2), 101-125.

Revilla, G., \& Dodd, T. H. (2003). Authenticity perceptions of Talavera pottery. Journal of Travel Research, 42(1), 94-99.

Roberts, J. A. (1995), “Profiling Levels of Socially Responsible Consumer Behavior: A cluster Analytic Approach and its Implications for Marketing,' Journal of Marketing Theory and Practice 3(4), pp. 97-118.

Robinson, R., \& Smith, C. (2002). Psychosocial and demographic variables associated with consumer intention to purchase sustainably produced foods as defined by the Midwest Food Alliance. Journal of nutrition education and behavior, 34(6), 316-325. 
Rokeach, M., 1973. The Nature of Human Values. John Wiley: Free Press, New York

Roozen, Irene, Patrick De Pelsmacker, and Frank Bostyn. 2001. The Ethical Dimensions of Decision Processes of Employees. Journal of Business Ethics, 33 (2): 87-99.

Roussou, M. (2004). Learning by doing and learning through play: an exploration of interactivity in virtual environments for children. Computers in Entertainment (CIE), 2(1), 10-10.

Roussou, M., Oliver, M., \& Slater, M. (2006). The virtual playground: an educational virtual reality environment for evaluating interactivity and conceptual learning. Virtual Reality, 10, 227-240.

Sachs, G. (2016). Virtual and augmented reality: Understanding the race for the next computing platform. Goldman Sachs Group, Inc. URL: http://www. goldmansachs. com/ourthinking/pages/technology-drivinginnovation-folder/virtual-and-augmentedreality/report. pdf. Accessed, 2019

Salzhauer, A. L. (1991). Obstacles and opportunities for a consumer ecolabel. Environment: Science and Policy for Sustainable Development, 33(9), 10-37.

Schlossberg, M. (2016). Teen Generation $Z$ is being called'millennials on steroids,'and that could be terrifying for retailers. Retrieved, 9, 2016.

Schuemie, M., Van Der Straaten, P., Krijn, M., \& Van Der Mast, C.A.P.G. (2001). Research on presence 850 in virtual reality: A survey. CyberPsychology \& Behavior, 4(2), 183-201.

Serva, C. (2016). Positivism in Sociology: Definition, Theory \& Examples - Video \& Lesson Transcript. Retrieved June 20, 2019, from Study.com website: http://study.com/academy/lesson/positivism-in-sociology-definition-theory-examples.html Shaw, D., \& Clarke, I. (1999). Belief formation in ethical consumer groups: an exploratory study. Marketing Intelligence \& Planning, 17(2), 109-120. 
Shaw, D., Shiu, E., \& Clarke, I. (2000). The contribution of ethical obligation and self-identity to the theory of planned behaviour: An exploration of ethical consumers. Journal of marketing management, 16(8), 879-894.

Shaw, D., \& Shiu, E. (2002). The role of ethical obligation and self-identity in ethical consumer choice. International Journal of Consumer Studies, 26(2), 109-116.

Shaw, D., \& Newholm, T. (2002). Voluntary simplicity and the ethics of consumption. Psychology \& Marketing, 19(2), 167-185.

Shen, J., \& Eder, L. B. (2009). Intentions to use virtual worlds for education. Journal of Information Systems Education, 20(2), 225.

Shin, D. H. (2008). Understanding purchasing behaviors in a virtual economy: Consumer behavior involving virtual currency in Web 2.0 communities. Interacting with computers, 20(4-5), 433-446.

Sikula, A., \& Costa, A. D. (1994). Are women more ethical than men?. Journal of Business Ethics, 13(11), 859-871.

Sparks, P., \& Shepherd, R. (1992). Self-identity and the theory of planned behavior: Assessing the role of identification with green consumerism. Social Psychology Quarterly, 55(4), 388-399

Sparrow, R., Harrison, R., Oakley, J., \& Keogh, B. (2018). Playing for fun, training for war: Can popular claims about recreational video gaming and military simulations be reconciled? Games and Culture, 13(2), 174-192.

Stangl, B., \& Weismayer, C. (2008). Websites and virtual realities: a useful marketing tool combination? An exploratory investigation. In P. O’Connor, W. Ho“pken, \& U. Gretzel 
(Eds.), Information and communication technologies in tourism 2008 (pp. 141-151). New York: Springer.

Stein, C. (2016). Virtual reality design: How head-mounted displays change design paradigms of virtual reality worlds. MediaTropes, 6(1), 52-85.

Steuer, J. (1992). Defining virtual reality: Dimensions determining telepresence. Journal of communication, 42(4), 73-93.

Stolle, D., Hooghe, M. and Micheletti, M. (2006), "Politics in the Supermarket: Political Consumerism as a Form of Political Participation”, International Political Science Review, Vol. 26, No. 3, pp. 245-269.

Suh, K. S., \& Chang, S. (2006). User interfaces and consumer perceptions of online stores: The role of telepresence. Behaviour \& information technology, 25(2), 99-113.

Suh, K. S., \& Lee, Y. E. (2005). The effects of virtual reality on consumer learning: an empirical investigation. Mis Quarterly, 673-697.

Sussmann, S., \& Vanhegan, H. (2000). Virtual reality and the tourism product: substitution or complement? Proceedings of the European conference on information systems 2000, paper 117 .

Tarkiainen, A., \& Sundqvist, S. (2005). Subjective norms, attitudes and intentions of Finnish consumers in buying organic food. British Food Journal, 107(11), 808-822.

Teisl, M. F., Roe, B., \& Levy, A. S. (1999). Ecocertification: Why It May Not Be a" Field of Dreams". American Journal of Agricultural Economics, 81(5), 1066-1071.

Thomasson, R. (2006). Augmented Reality: Get in touch with the past, Wired, pp. 40.

Titus, P. A., \& Bradford, J. L. (1996). Reflections on consumer sophistication and its impact on ethical business practice. Journal of Consumer Affairs, 30(1), 170-194. 
Trends in the Age Composition of College and University Students and Graduates. (2010).

Retrieved July 22, 2019, from https://www150.statcan.gc.ca/n1/pub/81-004x/2010005/article/11386-eng.htm

Tsalikis, J., \& Ortiz-Buonafina, M. (1990). Ethical beliefs' differences of males and females. Journal of Business Ethics, 9(6), 509-517.

Tunçer, B., \& Thidell, Å. (2004). The use of eco-labeling like initiatives on food products to promote quality assurance — is there enough credibility?. Journal of Cleaner production, 12(5), 517-526.

Tussyadiah, I. P., Wang, D., Jung, T. H., \& tom Dieck, M. C. (2018). Virtual reality, presence, and attitude change: Empirical evidence from tourism. Tourism Management, 66, 140-154.

Utting-Chamorro, K. (2005). Does fair trade make a difference? The case of small coffee producers in Nicaragua. Development in Practice, 15(3-4), 584-599.

Valkila, J., \& Nygren, A. (2010). Impacts of Fair Trade certification on coffee farmers, cooperatives, and laborers in Nicaragua. Agriculture and Human Values, 27(3), 321-333.

Vallerand, R. J., \& Blssonnette, R. (1992). Intrinsic, extrinsic, and amotivational styles as predictors of behavior: A prospective study. Journal of personality, 60(3), 599-620.

Vince, J. (2004). Introduction to virtual reality. New York: Springer

Vitell, S. J., Singhapakdi, A., \& Thomas, J. (2001). Consumer ethics: an application and empirical testing of the Hunt-Vitell theory of ethics. Journal of Consumer marketing, 18(2), 153-178.

Waitt, G. (2000) Consuming heritage: Perceived historical authenticity, Annals of Tourism research, 27, pp. 835-862 
Walsh, K. (2002). Reducing distance in e-Commerce using virtual reality. E-business handbook, St. Lucie Press, Boca Raton.

Weatherell, C., Tregear, A., \& Allinson, J. (2003). In search of the concerned consumer: UK public perceptions of food, farming and buying local. Journal of rural studies, 19(2), 233244.

Wessels, C.R., Johnston, RJ. and Donath, H. (1999), "Assessing consumer preferences for ecolabelled seafood: the influence of specie, certifier and household attributes", American Journal of Agricultural Economics, Vol. 81, pp. 1084-9.

Wexelblat, A. (1993). The reality of cooperation: virtual reality and CSCW. In Virtual Reality (pp. 23-44). Academic Press.

Who Invented Virtual Reality? (2017). Retrieved June 13, 2019, from Virtual Reality Society website: https://www.vrs.org.uk/virtual-reality/who-invented-it.html

Williams, A. P., \& Hobson, J. S. P. (1994). Tourism - The next generation: virtual reality and surrogate travel, is it the future of the tourism industry? In A. V. Seaton (Ed.), Tourism: The state of the art (pp. 283-290) Toronto: John Wiley \& Sons

Witmer, B. G., \& Singer, M. J. (1998). Measuring presence in virtual environments: A presence questionnaire. Presence, 7(3), 225-240.

Wood, S. (2013). Generation Z as consumers: trends and innovation. Institute for Emerging Issues: NC State University, 1-3.

Wydick, B. (2016). Reasons Fair-Trade Coffee Doesn’t Work”. Huffington Post.

Xia, P., Lopes, A. M., \& Restivo, M. T. (2013). A review of virtual reality and haptics for product assembly (part 1): rigid parts. Assembly Automation, 33(1), 68-77. 
Youngblut, C. (1998). Educational uses of virtual reality technology. Alexandria, VA: Institute for Defense Analyses. Retrieved from http://papers.cumincad.org/data/works/att/ 94ea.content.pdf

Yucel, I. H., \& Edgell, R. (2015). Conceptualizing Factors of Adoption for Head Mounted Displays: Toward an Integrated Multi-Perspective Framework. Edgell, Robert A. and Yucel, I.(2015). Conceptualizing factors of adoption for head mounted displays: Toward an integrated multi-perspective framework. Journal of Virtual World Research, 8(2), 1-10. Zavestoski, S. (2002). The social-psychological bases of anticonsumption attitudes. Psychology and Marketing, 19(2), 149-165. https://doi.org/10.1002/mar.10007 